
. \title{
aerosol properties in a background environment \\ Long-term comparative study of columnar and surface mass concentration
}

Correspondence to: V. Cachorro (chiqui@goa.uva.es)

\section{Abstract}

The relationship between columnar and surface aerosol properties is not a straightforward problem. The Aerosol Optical Depth (AOD), Ångström exponent (AE), and ground-level Particulate Matter $\left(\mathrm{PM}_{\mathrm{X}}, \mathrm{x}=10\right.$ or $\left.2.5 \mu \mathrm{m}\right)$ data have been studied from a climatological point of view. Despite the different meanings of AOD and PMx both are key and complementary quantities that quantify aerosol load in the atmosphere and many studies intend to find specific relationships between them. Related parameters such as $\mathrm{AE}$ and $\mathrm{PM}$ ratio $\left(\mathrm{PR}=\mathrm{PM}_{2.5} / \mathrm{PM}_{10}\right)$, giving information about the predominant particle size, are included in this study on the relationships between columnar and surface aerosol parameters. This study is based on long measurement records (2003-2014) obtained at two nearby background sites from the AERONET and EMEP networks in the north-central area of Spain. The climatological annual cycle of PMx shows two maxima along the year (one in latewinter/early-spring and another in summer), but this cycle is not followed by the AOD which shows only a summer maximum and a nearly bell shape. However, the annual means of both data sets show strong correlation $(\mathrm{R}=0.89)$ and similar decreasing trends of $40 \%\left(\mathrm{PM}_{10}\right)$ and $38 \%(\mathrm{AOD})$ for the 12-year record. $\mathrm{PM}_{10}$ and $\mathrm{AOD}$ daily data are moderately correlated $(\mathrm{R}=0.58)$, whereas correlation increases for monthly $(\mathrm{R}=0.74)$ and yearly $(\mathrm{R}=0.89)$ means. Scatter plots of AE vs. AOD and PR vs. $\mathrm{PM}_{10}$ have been used to characterize aerosols over the region. The PR vs. AE scatterplot of daily data shows no correlation due to the prevalence of intermediate-sized particles. As day-to-day correlation is low (especially for high turbidity events), a binned analysis was also carried out to establish consistent relationships between columnar and surface quantities, which is considered to be an appropriate approach for environmental and climate studies. In this way the link between surface concentrations and columnar remote sensing data is shown to provide useful information for aerosol characterization from a climatological context, despite some limitations. 
35 The relationships between surface and columnar aerosol properties are strongly impacted by high turbidity events. The best correlations are obtained for the annual scale.

\section{Introduction}

A common reference indicator for particulate air quality is the concentration of particulate matter (PM) at ground level, which is given in units of mass per unit volume of air $\left(\mu \mathrm{g} \mathrm{m}^{-3}\right)$. The PM size fraction represented by $\mathrm{PM}_{10}$ and $\mathrm{PM}_{2.5}$ are the most available and commonly used metrics. The $\mathrm{PM}_{10}$, often called "inhalable particles" (EMEP, 1996; Brown et al., 2013), refers to particle fraction with aerodynamic diameters less than $10 \mu \mathrm{m}$. In the same way, $\mathrm{PM}_{2.5}$ or "fine particles" (diameters below $2.5 \mu \mathrm{m}$ ) is another measure of particulate matter. The latter is associated to hazardous effects, having far greater efficiency than "coarse particles" $(2.5-10 \mu \mathrm{m})$ to penetrate the respiratory system and reach the alveolar regions. Consequently, $\mathrm{PM}_{10}$ is usually used as a standard for measuring aerosol loading, while $\mathrm{PM}_{2.5}$ is linked to health and visibility impacts (Pope III, 2000; Pope III and Dockeri, 2006).

In the last decades national and international institutions have set limits and guide values for the concentration of various PM size fractions with the aim to protect public health and environment (Delucchi et al., 2002; WHO 2006; EC, 1999, 2008). Although so far this objective has not been universally achieved (Füssel and Jol, 2012), decreasing trends in yearly average have been observed in many European countries (EMEP, 2011,2014; Tørseth et al., 2012; Cusack et al., 2012; Boucher et al., 2013; Querol et al., 2014). These reductions are certainly attributed in a great part to the application of these abatement strategies of air pollution (EMEP, 2014). A significant effort has been dedicated to the implementation of continuous ground-based "in-situ" monitoring networks. The European Monitoring and Evaluation Programme (EMEP) established these networks with the goal of studying Long-Distance Atmospheric Pollution. This network provides to scientific community and governments quantitative information on the transport of air pollutants across national boundaries, associated deposition and concentration levels (Tørseth et al., 2012; EMEP, 2011; 2014). However the EMEP PMx observations are too sparse to resolve the large spatial and temporal aerosol variability and thus other measurement techniques, such as remote sensing at ground-based or satellite platform, may also be used.

Other networks for aerosol studies are based on powerful remote sensing techniques, like AERONET (Aerosol Robotic Network), which was created in the 1990's as a federation of national and regional networks managed by NASA. It is a dense network of ground-based sun photometers 
around the globe (Holben et al., 1998). Such networks constitute a valuable source of information for the establishment of local and regional aerosol characterization and climatology (Holben et al., 2001; Dubovik et al., 2002; Toledano et al., 2007a; Bennouna et al., 2011; 2013; Mateos et al., 2015).

The primary aerosol parameter provided by remote sensing is the Aerosol Optical Depth (AOD), describing the extinction of the electromagnetic radiation in a given atmospheric column attributed to aerosols at a given wavelength. This is the key parameter for measuring the columnar aerosol load. The advantage of this methodology using radiation-particle interaction is the complementary information provided by AOD wavelength dependence, related to the size of particles. The Angström exponent (AE) derived from AOD wavelength dependence is the parameter supporting this kind of information being the smallest this parameter the largest the particles. However, the AOD is a complex function of the aerosol mass concentration, mass extinction efficiency, relative humidity, and vertical distribution of aerosols, and hence several authors have investigated the relationships between AOD and columnar aerosol volume/mass concentration, surface PMx, mass deposition, or other quantities (Cachorro and Tanré, 1997; Kacenelenbogen et al., 1996; Pelletier et al., 2007; Kokhanovsky et al., 2009; Rohen et al., 2011; Toledano et al., 2012, among others).

The AOD, as a parameter representing the extinction over the whole atmospheric column, has a theoretical link with columnar particle volume concentration or columnar mass concentration through the definition of volume/mass efficiency factor (Cachorro and Tanré, 1997; Kokhanovsky et al., 2009; Toledano et al., 2012), but the link of these columnar properties with surface concentration given by $\mathrm{PM}_{10}$ (or $\mathrm{PM}_{2.5}$ ) measurements is not a straightforward problem and hence empirical relationships are usually established (e.g., Estellés et al., 2012 and references herein; Rohen et al., 2011).

In this context and restricting the study to AOD data given by ground-based observations we are interested in the relationships $\mathrm{AOD}-\mathrm{PM}_{10}$ including derived quantities such as Ångström exponent $(\mathrm{AE})$ and ratio of $\mathrm{PMx}$ fractions $\left(\mathrm{PM}_{2.5} / \mathrm{PM}_{10}\right)$, related with particle size, which also need to be involved in the study of these relations. Thus, the objective of this work is to investigate in detail the relations between these four complementary parameters from a climatological point of view relying on 12 years of overlapping AOD and $\mathrm{PM}_{\mathrm{X}}$ data (2003-2014) over two background stations of the large region of "Castilla y Leon" in the North-central Iberian Peninsula. This plateau presents a clean continental background aerosol without local pollution and it is adequate for this kind of study. The sites belong to EMEP and AERONET-Europe networks respectively, which certify the quality of the used data. To our knowledge this is the first time that this kind of study is 
carried out taking an area with these characteristics and lengthy records, emphasizing the climatological aspect.

It is relevant to note here that in the study area the highest levels of PMx are attributed to desert dust intrusions (Rodríguez et al., 2001; Escudero et al., 2005, 2007; Toledano et al., 2007a; Cachorro et al., 2008), because events of high AOD can also be due to external anthropogenic pollution (showing less influence on PMx values). Impact of desert dust aerosols on AOD (Toledano et al., 2007b; Cachorro et al., 2013) and PMx (Querol et al., 2009; Cachorro et al., 2014; Pey et al., 2013) are of particular interest for the Mediterranean Basin because they have a strong influence on the relationships established hereafter which opens new perspective on their potential use in aerosol studies.

The paper begins by introducing the region of study (section 1) and the description of the datasets (section 2). The results are presented in several sections. Section 3.1 gives a brief analysis of the annual cycle, interannual variability and temporal trends. In section 3.2, columnar scatter plots of AOD-AE and surface scatter plots $\mathrm{PM}_{10}-\mathrm{PR}$ are examined in order to address general findings in terms of general aerosol characterization. Section 3.3 establishes and analyses the relationship $\mathrm{PM}_{10}$-AOD and section 3.4 the PR-AE one. Section 3.5 gives the latter relationships under the analysis of binned data.

\section{Measurement sites and data}

The locations of the two sites used in this study are presented in Figure 1: the rural village of Peñausende (41.24N, 5.90W, 985m. a.s.1.) and Palencia City (41.99N, 4.52W, 750 m. a.s.1.), both belonging to the autonomous community of "Castilla y León" $(\mathrm{CyL})$. This region located in the North Central part of the Iberian Peninsula lies on the northern plateau of Spain (Castilian Plateau), which has an average altitude of $\sim 800 \mathrm{~m}$, and is crossed by the Duero River, forming a narrow valley. The Castilian Plateau is surrounded by mountains (about 2000-2500 m) that reduce Atlantic and Mediterranean influences, thus leading to the continental climate characterizing this region. The CyL region spans a territory of $94193 \mathrm{~km}^{2}$ with 27 inhabitants per $\mathrm{km}^{2}$, making it the most sparsely populated region of Spain. The biggest metropolitan center of the region is Valladolid City ( 400,000 habitants). The small city of Palencia ( 100,000 inhabitants) is located about $50 \mathrm{~km}$ to the northeast of Valladolid. The little village of Peñausende ( 500 habitants) is located in the province of Zamora, about $100 \mathrm{~km}$ to the east of Valladolid. Both Palencia and Peñausende sites, are relatively well isolated from big urban and industrial centers, and can therefore be classified as regional background sites. 
At Peñausende, PMx measurements have been carried out continuously since 2001 by means of gravimetric methods, however we only used data from 2003 onward for the overlapping period with AOD data. The samples are collected on quartz fiber filters using MCV-PM1025 high-volume samplers operating at an average flow rate of $30 \mathrm{~m}^{3} \mathrm{~h}^{-1}$ with $10 \mu \mathrm{m} / 2.5 \mu \mathrm{m}$ cut-off inlets. Sample treatment, analytical procedures and quality assurance were performed according to the details described in the EMEP Manual for Sampling and Chemical Analysis (EMEP, 1996). The PM 10 and $\mathrm{PM}_{2.5}$ samplings were carried out on a daily basis. Table 1 sums up the number of EMEP PMx measurements available by year. On average, $90 \%$ of yearly data are usable. The PR values are derived from the two independent PMx measurements when both are available.

Columnar aerosol properties, here aerosol optical depth and Ångström exponent, are derived by direct sun and sky radiation sunphotometer measurements. The AOD gives the total load of aerosol over the vertical column and it is generally measured at various wavelengths. This spectral wavelength dependence defines the AE parameter related to particle size (Cachorro et al., 2000; Vergaz et al., 2005; Toledano et al., 2007a), and thus gives information about the prevalence of fine or coarse fractions. The AERONET AOD at 440nm and the AERONET derived value for AE, using wavelengths in the range 440-870nm, are used in this study.

A Cimel sunphotometer belonging to RIMA (Iberian Network for Aerosol Measurements) located at the outskirts of Palencia (University Campus, Superior Technical School of Forestry and Agricultural Engineering) and operating in the frame of AERONET-EUROPE (Holben et al., 1998; Goloub et al., 2012), provided continuous aerosol measurements from 2003 to 2014 with the exception of a long period between 2009 and 2010. This gap in Palencia data was completed by values from Autilla station, another nearby RIMA-AERONET site (3 km apart from Palencia city; Bennouna et al., 2013). Raw AOD data provided every 15 minutes by direct sun radiation measurements are cloud-contaminated (level 1.0), thus an automatic cloud screening algorithm (Smirnov et al., 2000) is applied to obtain level 1.5. The final data level named "quality assured" level 2 is the one used in this study, where pre- and post-calibration are accounted for with a final manual inspection according to AERONET protocols. The AOD accuracy for level 2 AERONET is about 0.01 in the visible and near infrared spectral regions (Eck et al., 1999).

We must emphasize that the distance between both monitoring sites $(\sim 100 \mathrm{~km})$ is not an obstacle to link the aerosol properties in this representative area of the North-central Spain, because the plateau between them with no relevant local aerosol sources and where external events of high turbidity are clearly identified at both sites at the same time. Otherwise, the different intrinsic 
168

169

170

171

172

173

174

175

176

177

178

179

180

181

182

183

184

185

186

187

188

189

190

191

192

193

194

195

196

197

198

199

200

201

measure while daily sun-photometer data are based on nearly instantaneous, every 15-minutes, values) seem to play a major role on the AOD-PMx differences.

\section{Results}

\subsection{Climatological annual cycle, variability and trends of AOD, PMx, AE and PR.}

A quick description of the annual cycle from 2003 to 2014 is shown for AOD, AE, PM 10 and PR quantities in Figure 2, and Figure 3 presents their respective interannual variability; associated statistical values are reported in Tables 2-5. At Peñausende the mean value and standard deviation of $\mathrm{PM}_{10}$ is $10.6 \pm 9.0 \mu \mathrm{g} \mathrm{m}^{-3}$ and the AOD at Palencia is $0.13 \pm 0.09$, given a ratio of $81.5 \mu \mathrm{g} \mathrm{m}^{-3}$ per unit of AOD (near 100). What stands out is the high standard deviations of $85 \%$ and $69 \%$ respectively, indicating high variability (also shown by Tables 2-3). The most important feature is the low level of aerosol load in the study area representative of a rural regional background.

\subsubsection{Climatological annual cycle}

The climatological annual cycle of $\mathrm{PM}_{10}$ (see Figure 2a) is characterized by high values in late-winter/early-spring and summer, and low values in winter and fall, with two maxima, one in March $\left(11.4 \mu \mathrm{g} \mathrm{m}^{-3}\right)$ and the other in August $\left(14.7 \mu \mathrm{g} \mathrm{m}^{-3}\right)$, with a pronounced minimum between them. Like for $\mathrm{PM}_{10}$, the lowest values of the AOD are found in winter $(\sim 0.09)$ and the highest values in summer $(\sim 0.15)$ with increasing (decreasing) values in spring (fall) resulting in a nearly bell shaped annual cycle. However, no relevant minimum in spring appears for the AOD, although a slight minimum can be observed in May. Therefore, the most obvious difference between the mean annual cycles of $\mathrm{AOD}$ and $\mathrm{PM}_{10}$ is the presence of these two clear seasonal maxima for $\mathrm{PM}_{10}$.

Although it is not shown here, the climatological curve of $\mathrm{PM}_{2.5}$ presents the same variations and shape as that of $\mathrm{PM}_{10}$. The $\mathrm{PM}_{10}$ and $\mathrm{PM}_{2.5}$ data are strongly correlated with a Pearson coefficient of $\mathrm{R}=0.89$ and a slope of 0.58 , which corresponds to the mean value of PR. Thus the annual cycle of PR (Figure 2b) shows very little variation in the monthly means with slightly higher values in winter, being nearly constant around the average value of $0.58 \pm 0.15$ (Table 3 ). The Ångström exponent is also rather constant throughout the year, with an average value of $1.28 \pm$ 0.37 , but with lower values in winter-spring than during summer-early fall. Therefore, there is a discrepancy between PR and AE annual cycles during summer months. For both PR and AE parameters, day-to-day variations within a month are generally large for all months as indicated by the great variability associated to the means (Tables 2-3 and Figure 2), but they present monthly means around their total average and hence these two parameters correlate poorly, as discussed later. From the analysed variations it seems that PR is relatively less sensitive to particle size 
variations as compared to AE. This may be also noted when analysing in detail major desert dust 203 events that lead to an important decrease of the AE parameter while PR values remain little affected in these cases (Cachorro et al., 2013, 2014). These results show that on average aerosol particles of intermediate size are representative of the north central area of the Iberian Peninsula.

As mentioned, the area of "Castilla y León" is characterized by prevalent clean atmospheric conditions with the occurrence of moderate-to-strong desert dust intrusions or long-range transported pollutants of anthropogenic origin (see P95 percentiles in Tables 2-3). We must bear in mind that in this area only desert dust (DD) outbreaks contribute substantially to the values of PMx, whereas fine particles which characterize anthropogenic pollution aerosols events, have relatively

211 less influence over mass concentration. On the contrary, AOD is impacted in a similar way by both 212 types of events. This fact partly explains the differences between both annual cycles, one of the 213 most important causes being the vertical distribution of aerosols and the complex deposition 214 processes introducing different time delay between surface and columnar detections. Another 215 reason is the intrinsic differences in measurement techniques of both quantities, as already 216 mentioned.

\subsubsection{Interannual variability and trends}

A moderate year-to-year variability of both $\mathrm{PM}_{10}$ and AOD data is observed in Figure $3 \mathrm{a}$ with a similar decreasing trend during the period 2003-2014. Using the Mann-Kendall Trend Test with the Sen's Slope method (e.g., Mateos et al., 2015), $\mathrm{PM}_{10}$ gives a trend of $-0.42 \mu \mathrm{g} \mathrm{m}^{-3}$ per year with a $95 \%$ confidence interval of $[-0.55,-0.3]$, thus resulting in a reduction of $40 \%$ during the period 2003-2014. The AOD trend is $-0.005(-38 \%)$ with a confidence interval of $[-0.007,-0.004]$. Hence, both parameters show similar reduction, which suggests that the evolution of one of these parameters can be inferred from the other. These decreasing trends and possible causes have been analysed recently by various authors for PMx data (Barmpadimos et al., 2012; Cusack et al., 2012; Querol et al., 2014; Mateos et al., 2015) and for AOD (Mateos et al., 2014, 2015) over the Iberian Peninsula. Although not relevant, the differences between the results of these authors can be attributed to the use of different mean values (yearly or monthly), periods and methods.

Figure $3 \mathrm{~b}$ presents the inter-annual variability for the PM ratio and AE parameters, where $\mathrm{AE}$ appears to be more variable than PR (also at monthly level, not shown here). Though weak as compared to that of $\mathrm{AOD} / \mathrm{PM}_{10}$, there is also a decreasing trend which is more pronounced in $\mathrm{PR}$ and less obvious in AE. For each year PM ratio remains relatively constant throughout the seasons with some slight differences between one year and the other during summer (not shown). On the contrary, for AE the shape of the seasonal pattern appears to be different from one year to the next, 
thus on a monthly level AE parameter is more variable than PR. In order to properly interpret these 237 results, we must bear in mind that $\mathrm{AE}$ can vary from 0 to 2.5 while PR range is between 0 and 1. 238 The PR exhibits a reduction trend over the 12 analysed years of $22 \%$ (due to the fact that $\mathrm{PM}_{2.5}$ presents a reduction of $\sim 60 \%$ ) whereas $\mathrm{AE}$ only shows $8 \%$ reduction (value within the range of annual variability), which highlights the fact that each quantity is related to particle size in a different way: PR linked with the strong reduction of particle concentration and AE more linked with the AOD spectral dependence (remember that the effectivity of particle-radiation interaction is related to the size of particles and the range of wavelength).

It is important to note here that the observed differences between these surface and columnar properties cannot be attributed to different samplings (i.e. total number daily data around $70 \%$ for AOD against $90 \%$ for "in-situ" data), since the climatological analysis using only $\mathrm{PM}_{10}$-AOD coincident pairs yields to similar results. Bear in mind that PMx measurements are made under all weather conditions including overcast and/or partially cloudy conditions where there are no or few available data for the AOD. Cloud screening in AOD measurements under highly variable turbidity episodes (such as relatively strong desert dust intrusions) affected by clouds is extremely difficult. Therefore, specific cases such as a desert dust episodes clearly detected by PMx data, may not be visible in AOD, leading to discrepancies in monthly means which in turn affect yearly means. In the present data set yearly means are not affected by these sampling issues and correlate strongly as shown later on (section 3.2.2). However, if a high discrepancy in PMx-AOD yearly mean is observed, it is reasonable to suspect possible problems in the database.

relevant to know previously the distinct behaviour of each pair: AE-AOD on one hand and PR$\mathrm{PM}_{10}$ on the other.

\subsubsection{AE-AOD columnar relationship}

Figure 4 is a plot of the AE parameter versus AOD for daily (figure 4a-b) and instantaneous databases (Figures $4 \mathrm{c}-\mathrm{d}$ ) with values of $\mathrm{PM}_{10}(\mathrm{a}, \mathrm{c})$ and $\mathrm{PR}(\mathrm{b}, \mathrm{d})$ represented by a colour scale. For shake of clarity, Figures S1 and S2 (supplementary material) separately show each category of $\mathrm{PM}_{10}$ or PR and a 3D plot of the AE vs. AOD. These AE-AOD scatterplots of intensive-extensive quantities are part of the general site aerosol characterization and hence frequently used in columnar aerosol studies. Indeed they link particle size with the amount of aerosols allowing to classify or 
discriminate aerosol types according to defined aerosol climatological models, such as continental, maritime, desert dust, biomass burning, etc. (Hess et al., 1998; Eck et al., 1999; Vergaz et al., 2005; Toledano et al., 2007a) and to quantify their respective contribution. The $\mathrm{PM}_{10}$ and $\mathrm{PR}$ range values in the graphs of Figure 4 allow a comprehensive analysis of these four quantities, and together with Figure 5 are necessary for a deeper interpretation of the relationship between them.

As it can be seen in Figure 4a, most AOD-AE daily averages (about 80\%) are in the range of 0.0-0.2 and 1.0-2.0 respectively, which are typical of a clean continental area (e.g., Toledano et al., 2009; Bennouna et al., 2013). $\mathrm{PM}_{10}$ values from 0-10 $\mu \mathrm{g} \mathrm{m}^{-3}$ (50\% of total) extend over the whole range of AOD with $47 \%$ corresponding to AOD $\leq 0.10$ (inset in Figure $4 a$ ). For these data sets AE parameter also cover all range of sizes from 0 to 2 . These values of $\mathrm{PM}_{10}$ below $10 \mu \mathrm{g} \mathrm{m}^{-3}$ together with those between $10-20 \mu \mathrm{g} \mathrm{m}^{3}$ (38\% of data) are the most frequent and extend over all the ranges of the plot (dark and light blue points), considerably surpassing the AOD value of 0.2 and even reaching the highest AOD values. Bearing in mind that the average of AOD is $0.13 \pm 0.9$, mean value plus the standard deviation is 0.22 , therefore values higher than this threshold may be considered events of high turbidity in this area, being considered as high-to-moderate between 0.2-0.3 and higher than 0.3 as strong-extreme cases. These cases of high turbidity represent $18 \%$ of the total AOD database. On the other hand, $\mathrm{PM}_{10}$ values larger than $20 \mu \mathrm{g} \mathrm{m}^{-3}$ only represent $12 \%$ of total data which are represented by green points in Figure $4 \mathrm{a}\left(\mathrm{PM}_{10}\right.$ between 20 to $40 \mu \mathrm{g} \mathrm{m}^{-3}$ with AOD from 0.1 to 0.6$)$ and red-brown points $\left(\mathrm{PM}_{10}\right.$ greater than $40 \mu \mathrm{g} \mathrm{m}^{-3}$ are only $2.6 \%$ of the total values, thus few days correspond to strong-extreme events of high turbidity) in Figure 4a.

The same can be observed in Figure $4 \mathrm{c}$ corresponding to instantaneous values, which illustrates a more detailed information and provides a better view of the results. For example, the particularly strong extreme events in AOD correspond to intense desert dust intrusions of very low

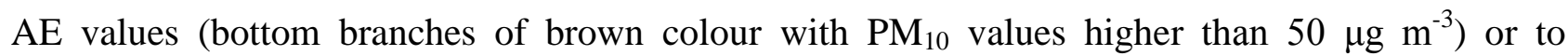
anthropogenic pollution events coming from far off areas of our region with high values of AE (top branches of green colour). Furthermore, mixed aerosol type (blue light colour) with values of AE in 1-1.5 but moderate $\mathrm{PM}_{10}$ values (10-20 $\mu \mathrm{g} \mathrm{m}^{-3}$ interval) are clearly visible in the centre of Figure $4 \mathrm{c}$. Although these two figures $(4 \mathrm{a}, \mathrm{c})$ allow a good characterization of aerosols, we must note that in general there is a great mixing between the different range of values of both $\mathrm{PM}_{10}$ and AOD data. This behaviour means a weak connection between AOD and $\mathrm{PM}_{10}$ under certain conditions when taking daily data, as discussed later on.

With respect to particle size Figures $4 \mathrm{~b}$,d illustrate the behaviour of daily and instantaneous AE-AOD values but now with the colour scale representing PR values. Values of PR below 0.3 are not frequent (blue points: $2 \%$ of total) and also correspond to the lowest AE values. These values 
represent very pure desert dust aerosols (or weakly mixed with other aerosol types during transport) with values of AOD beyond 0.2. The PR values between 0.3-0.5 (green points, 19\%) are largely missing from the figure but they span the whole range of $\mathrm{AE}$ (between low values up to 2 ) and AOD. The majority of PR daily data (purple points, 50\%) range from 0.5 to 0.7 and cover all the ranges on the AE-AOD plot with the exception of extreme desert dust (bottom-right area). These $\mathrm{PR}$ values represent medium particle size, also corroborated by AE values (observe the branches at $\mathrm{AE} \sim 1.3$ and that at 1.8), and include pollution episodes with the highest AOD (right-top branches) which is not the case for $\mathrm{PM}_{10}$. The PR values larger than 0.7 (orange, red and brown colours points, $\sim 23 \%$ ) point out particles of medium-to-fine size and hence have values of AE greater than 1 and with AOD values up to 0.4. The region around $\mathrm{AE} \sim 1.2-1.5$ and $\mathrm{AOD} \sim 0.1$ corresponds to the highest density of data points.

\subsubsection{Surface PR-PM ${ }_{10}$ Relationship}

Figures 5a-b presents the scatterplots of daily data of PR versus $\mathrm{PM}_{10}$ (equivalent to Figures $4 a-b$ for AE-AOD) with values of AOD and AE represented by a color scale. For shake of clarity, Figures S3 and S4 (supplementary material) separately show each category of AOD or AE and a 3D plot of the PR vs. PM $\mathrm{PM}_{10}$. These scatterplots are not usually analysed in air quality studies based on PMx data. As only daily values are available for these quantities, there is a certain limitation in the information compared to the combination of AOD-AE data (Figure $4 \mathrm{c}-\mathrm{d}$ ), especially when events must be analysed in detail. The most curious is the shape the data points take in the figure, curves resembling those of "the wings of a butterfly", which are due to the low values of PMx where the points are discretized (integer values for $\mathrm{PM}_{10}$ and $\mathrm{PM}_{2.5}$ ) and superimposed. As it can be seen, only for very low PR values (less than 0.4 ) or larger $\mathrm{PM}_{10}$ values (about $20 \mu \mathrm{g} \mathrm{m}^{-3}$ ) the points appear as scattered points in the figure. This discretized behaviour makes that important information is missing in the figure. Blue points are masked in Figure 5a (this information can be seen in supplementary material), and they correspond to AOD from 0 to 0.2 and account for the majority of all points.

In Figure $5 \mathrm{~b}$ (with $\mathrm{AE}$ in the colour scale) only the range of light-green points for $\mathrm{AE}$ between 1-1.5 are masked by superimposed dark-green points of $\mathrm{AE}$ values between 1.5 and 2. Both ranges, representing medium and fine particles, are the most abundant. Obviously, most of the behaviour shown by Figure 5 is already described in Figure 4. However, it is relevant to conclude that AODAE scatterplot for daily data contain more useful information than that of $\mathrm{PM}_{10}-\mathrm{PR}$. The reason behind this behaviour is that $\mathrm{AE}$ has more valuable information about particle size than PR, as mentioned before. Actually, PR is a simple ratio of concentrations but AE contains the spectral 
338 AOD dependence, which according to the Mie Theory carries useful information about particle size

339 because of the complex interaction of particle and radiation.

\subsection{Relationships between columnar and surface load of aerosols, PM10-AOD.}

The useful information given by the above plots will help us to better interpret the $\mathrm{PM}_{10}$-AOD relationship. Figure $6 \mathrm{a}-\mathrm{b}$ shows this relationship using the 2622 coincident days where AE and PR values are represented by a colour scale, respectively. The moderated-to-low correlation of $\mathrm{PM}_{10^{-}}$ AOD is due to the bulk of points covering the different ranges of values as analysed before. For instance, calues of $\mathrm{PM}_{10}$ below $20 \mu \mathrm{g} \mathrm{m}^{-3}$ contain most of the AOD values up to 0.3 . There are very

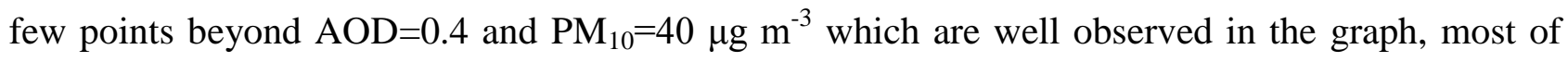
them corresponding to desert dust intrusions (e.g., Cachorro et al., 2008; 2013; 2014) as it is indicated by the blue colour of AE and PR. Days of anthropogenic pollution are also detected with moderated-to-high values of $\mathrm{AE}$ and PR (purple and orange colours). As expected, in general $\mathrm{PM}_{10}$ values increase with AOD but with a wide range of variation. For episodes of high-to-extreme intensity, both $\mathrm{AOD}$ and $\mathrm{PM}_{10}$ present high values and their correlation is very dependent on the type of episode (anthropogenic pollution or desert dust) and on atmospheric conditions. For example, in the case of desert dust episodes there are important day-delays between the detection by $\mathrm{PM}_{10}$ and by AOD, which cannot be explained easily due to the complex deposition processes.

The correlation established in Figure 7a for daily data presents a slope of 62.7 and an intercept of 3.5 (a slope of 80.0 is obtained when the line is constrained to pass through the origin). As expected, and considering other works (e.g., Kacenelenbogen et al., 2006; Estellés et al., 2012), these two parameters are moderately correlated with a correlation coefficient of 0.61 ( $\mathrm{p}$-value less than 0.001$)$, lying between the $95 \%$ confidence interval (0.54-1). The $\mathrm{PM}_{10}$-AOD correlation is improved when considering monthly means (Figure $7 \mathrm{~b}$ ) increasing the correlation coefficient to 0.74 (p-value less than 0.001), with a slope of 69.4 and an intercept of 2.3. Finally the correlation for yearly data (Figure 7c) has a similar slope to monthly data and an intercept of 1.4, with a very high correlation coefficient $\mathrm{R}=0.9$. Indeed, a likely primary reason for this overall moderate correlation is the high variability of aerosols in a short range of $\mathrm{AOD}$ and $\mathrm{PM}_{10}$ due to the clean conditions of the area where the prevailing particles (about 85\%) are medium-to-fine size with AE between 0.8-1.7 and PR between 0.5-0.8. These aerosol particles have a large influence on AOD but 


\subsection{Relationships between columnar and surface particle size parameters: PR-AE.}

Finally, Figure 8 plots $\mathrm{PR}$ versus $\mathrm{AE}$ with values of $\mathrm{AOD}$ and $\mathrm{PM}_{10}$ represented by a colour scale. For shake of clarity, Figures S5 and S6 (supplementary material) separately show each category of AOD or $\mathrm{PM}_{10}$ and a 3D plot of the PR vs. AE. As can be seen, a very low correlation exists between daily values of both parameters because dark and light blue colours extend everywhere covering all the AE-PR ranges. Green points that represent high turbidity events of moderate-to-high intensity, i.e. AOD in the range $(0.2,0.4)$ and $\mathrm{PM}_{10}$ in $\left(20,40 \mu \mathrm{g} \mathrm{m}^{-3}\right)$, are mainly positioned over the range of fine particles (towards the right-top about $\mathrm{PR}=0.7$ and $\mathrm{AE}=1.5$ ) but also extend everywhere. Finally red-brown points of very high and extreme turbidity episodes appear defined by two clusters (although with some sparse points) for AOD (Figure 8a) but not for $\mathrm{PM}_{10}$ (Figure 8b). One cluster given by desert dust type (bottom-left) appears in both Figures 8a-b but the cluster representing anthropogenic aerosols (industrial, urban, or biomass burning, right-top) is not well defined for $\mathrm{PM}_{10}$ values in Figure $8 \mathrm{~b}$. One possible reason may be that mineral dust particles have a larger density as compared to anthropogenic aerosols for the same AOD value because the former have a larger impact on the mass concentration over the PMx filters.

These established correlations are highly site-dependent and this limits its possible application to other areas but they may be useful when there is a lack of $\mathrm{PM}_{10}$ or AOD data over long time periods. Furthermore, we have observed that the non-correspondence between both quantities for yearly data (for example AOD increase with a $\mathrm{PM}_{10}$ decrease) allows the detection of possible problems in the data series.

\section{5. $P M_{10}-A O D$ and $P R-A E$ relationship using binned data.}

Finally, because of the low correlation in the day-by-day data between the four quantities as described above, in Figure 9 we have examined using binned data fundamental PM 10 -AOD and PRAE relationships but also the complementary relationships $\mathrm{PM}_{10}-\mathrm{AE}$ and PR-AOD. In Figure 9a, $\mathrm{PM}_{10}$ is represented as a function of the binned AOD, in the interval $0-1$ by steps of 0.05 . Each point of the curve corresponds to $\mathrm{PM}_{10}$ average for a given bin of $\mathrm{AOD}$, and the associated standard deviation is represented by vertical bars. As shown, $\mathrm{PM}_{10}$ increases slowly and regularly as the AOD reaches about 0.25 , but beyond this value the increasing slope is more irregular until $\mathrm{PM}_{10}$ reaches a maximum of about $47 \mu \mathrm{g} \mathrm{m}^{-3}$ (at AOD 0.55). For AOD > 0.55 there are only few data (see histogram) with irregular increasing or decreasing behaviour of $\mathrm{PM}_{10}$ values, which correspond to exceptionally strong events of high atmospheric turbidity. These highest AOD with the highest $\mathrm{PM}_{10}$ values (i.e., appearing as scattered points in Figure 4 and 6) belong in general to desert dust 
intrusions (as the study case of July 2004 described in Cachorro et al., 2008), while other are due to episodes of anthropogenic pollution or biomass burning.

In these cases both types of data, $\mathrm{PM}_{10}$ and/or AOD data detect the existence of a strong event but do not always correspond in time. In the case of desert dust outbreaks for example, the maximum of $\mathrm{AOD}$ is not always coincident with the maximum of $\mathrm{PM}_{10}$ on a daily basis. This is 410 because of the sedimentation process, as it is the case for the episode of low AOD and high $\mathrm{PM}_{10}$ 411 observed in Figure 7a (dark green point corresponding to the month of May). In the case of strong 412 anthropogenic pollution episodes the high AOD is generally accompanied by lower $\mathrm{PM}_{10}$ values as 413 compared with desert dust intrusions.

414 These results are corroborated by Figure 9b, which is analogous to Figure 9a but this time 415 with $\mathrm{PR}$ instead of $\mathrm{PM}_{10}$. The slight increase in $\mathrm{PM}_{10}$-AOD observed in the previous graph for low 416 AOD is reflected here in the nearly constant behaviour of PR around 0.6, being practically 417 independent of the AOD. For the last points with AOD higher than 0.5 (a very irregular zone), PR 418 presents minima in the same AOD bins where the maxima are observed for the $\mathrm{PM}_{10}$ and vice versa, 419 indicating a high correlation between bin-averaged data of PR-PM $\mathrm{P}_{10}$. This explains the fact that high 420 episodes are well detected by the two data series of $\mathrm{PM}_{10}$ and AOD, but not necessarily with a 421 systematic day-to-day correlation.

Figures 9c-d present analogous plots where the same data are binned according to AE values. As expected and observed in Figure 9c, $\mathrm{PM}_{10}$ bin-averaged and associated standard deviation are the highest for the lowest AE values, which correspond to the occurrence of desert dust intrusions. The highest $\mathrm{PM}_{10}$ values decrease sharply until $\mathrm{AE}=0.6$, followed by a nearly stable behaviour for $\mathrm{AE}$ values above 0.7. This result for $\mathrm{PM}_{10}-\mathrm{AE}$ highlights the well-known inverse correlation AODAE for desert dust episodes. In Figure 9d, PM ratio increases monotonically and smoothly with the increase of $\mathrm{AE}$ in all $\mathrm{AE}$ ranges, just breaking at both extremes where irregularities occur under desert dust (left) or high-pollution (right) episodes. This figure emphasizes the existence of a low correlation between these two parameters as illustrated also by Figure 8. It is only under very high or extreme episodes with very low or very high AE or PR values, when both quantities present a clear correspondence.

\section{Conclusions}

In this study long-term data (2003-2014) of two nearby background sites in the North-central Iberian Peninsula were used to analyse the relationship between surface and columnar aerosol loads considering $\mathrm{PM}_{10}, \mathrm{AOD}, \mathrm{AE}$ and $\mathrm{PR}$ data, where $\mathrm{PM}_{10}$ and $\mathrm{AOD}$ indicate the aerosol load, and $\mathrm{AE}$ and PR are related with particle size. The different relationships between these four quantities are 
investigated from a climatological point of view which also provides a general characterization of these key aerosol properties in a regional background environment.

This perspective is different of that presented in previous studies, mainly focused on establishing empirical relations between PMx $(x=10 \mu \mathrm{m}$ or $2.5 \mu \mathrm{m})$ and AOD in order to estimate or predict PMx, as a parameter that addresses air quality over big cities or large polluted areas. In most of these cases the AOD is provided by satellite sensors, which indeed presents the great advantage of large spatial coverage, but also carries much larger uncertainty as compared to ground-based measurements. Here, the study is carried out over a clean environment where the synergies between surface and columnar aerosol properties are long-term established.

The different relationships between these surface-columnar quantities are analysed by means of scatterplots because of their ability to show nonlinear relationships between the different parameters. In this study, not only the correlation between the aerosol load represented by $\mathrm{PM}_{10}$ and AOD is thoroughly analysed, but also their relations with AE and PR. Although there is, to a greater or lesser extent, a physical-theoretical basis to support the existent relationships between them, the complex physical processes and the dependences on other involved factors give rise to consideration of these relations from an empirical point of view. As a consequence, the mathematical expressions sometimes established (e.g., simple linear equation), are not always recommended.

Although the encountered correlations are generally low for daily data, they improve considerably for monthly or yearly means, and give very consistent relationships for binned data. As already mentioned these relationships depend on the aerosol characteristics of the site, and because of the clean and background conditions of our study area, they present a short range of $\mathrm{AOD}$ and $\mathrm{PM}_{10}$ values compared to other more polluted areas.

Despite the limitations mentioned throughout the paper, it is shown that for long-term series the synergy between surface and columnar remotely sensed data can still be quantitatively explored to provide useful information for aerosol characterization and general trends from a climatological point of view.

Acknowledgements. The authors are grateful to EMEP and MAGRAMA ("Ministerio de Agricultura, Alimentación y Medio Ambiente" of Spain) for providing PMx observations. Special thanks also go to NASA/GSFC, PHOTONS/LOA and RIMA/GOA people for their longstanding collaboration and for operating and maintaining the AERONET network. Thanks to MINECO for the financial support of the FPI grant BES-2012-051868; “Juan de la Cierva - Incorporación” grant IJCI-2014-19477 and project CMT2015-66742-R. We also thaks to the Environmental Council of 
the CyL Regional Government ("Consejería de Medio Ambiente, Junta de Castilla y León”) for supporting this research about atmospheric aerosols as well as Consejería de Educación for supporting the project VA100U14. Furthermore, the research leading to these results has received funding from the European Union Seventh Framework Programme (FP7/2007-2013) under grant agreement Nr. 654109 [ACTRIS 2].

\section{References}

Barmpadimos, I., Keller, J., Oderbolz, D., Hueglin, C., Prévôt, A.S.H., 2012. One decade of parallel fine (PM2.5) and coarse (PM10-PM2.5) particulate matter measurements in Europe: trends and variability. Atmos. Chem. Phys. 12, 3189-3203. DOI:10.5194/acp-12-3189-2012.

Bennouna, Y., Cachorro, V. E., Toledano, C., Berjón, A., Prats, N., Fuertes, D., González R., Rodrigo, R., Torres, B., de Frutos, A., 2011. Comparison of atmospheric aerosol climatologies over southwestern Spain derived from AERONET and MODIS. Remote Sens. Environ. 115, 1272-1284. DOI:10.1016/j.rse.2011.01.011.

Bennouna, Y., Cachorro V.E., Torres, B., Toledano, C., Berjón, A., de Frutos, A., Alonso Fernández-Coppel, I., 2013. Atmospheric turbidity and the annual cycle of aerosol optical depth over north-center Spain with ground (AERONET) and satellite (MODIS) remotely sensed data. Atmos. Environ. 67, 352-364.

Boucher, O., Randall, D., Artaxo, P., Bretherton, C., Feingold, G., Forster, P., Kerminen, V.M., Kondo, Y., Liao, H., Lohmann, U., Rasch, P., Satheesh, S.K., Sherwood, S., Stevens, B., Zhang, X.Y., 2013. Clouds and Aerosols, In: Climate Change 2013: The Physical Science Basis. Contribution of Working Group I to the Fifth Assessment Report of the Intergovernmental Panel on Climate Change 2013 [Stocker, T.F., Qin, D., Plattner, G.K., Tignor, M., Allen, S.K., Boschung, J., Nauels, A., Xia, Y., Bex, V., Midgley, P.M. (des)]. Cambridge University Press Cambridge, United Kingdom and New York, NY, USA.

Brown, J.S., Gordon, T., Price, O., Asgharian, B., 2013. Thoracic and respirable particle definitions for human health risk assessment. Part. Fibre Toxicol. 10, 10-12. DOI:10.1186/17438977-10-12.

Cachorro, V.E., Tanré, D., 1997. The correlation between particle mass loading and extinction: application to desert dust aerosol content estimation. Remote Sens. Environ. 60, 187194.

Cachorro, V.E., Duran, P., De Frutos, A.M., Vergaz, R., 2000. Measurements of the atmospheric turbidity of the north-center continental area in Spain: spectral aerosol optical thickness and Angstrom turbidity parameters. J. Aerosol. Sci. 31, 687-702.

Cachorro, V.E., Toledano, C., Prats N., Sorribas, M., Mogo, S., Berjón, A., Torres, B., Rodrigo, R., de la Rosa, J., De Frutos, A.M., 2008. The strongest desert dust intrusion mixed with smoke over the Iberian Peninsula registered with Sun photometry. J. Geophys. Res. 113, D14S04. DOI:10.1029/2007JD009582.

Cachorro, V.E., Burgos, M.A., Bennouna, Y., Toledano, C., Herguedas, A., González Orcajo, J., de Frutos, A.M., 2013. Inventario del Aerosol Desértico en la Región de Castilla y León (20032012). In Proceedings Book of the $1^{\text {st }}$ Iberian Meeting Aerosol Science and Technology RICTA 2013, Evora, Portugal. Edited by Maria João Costa, Ana Maria Silva, Juan Luis Guerrero Rascado, Sérgio Pereira, Daniele Bortoli and Rui Salgado. (ISBN: 978-989-20-3962-6). Available at http://www.ricta2013.cge.uevora.pt/wp-content/uploads/2013/10/E-ProcBook-RICTA2013.pdf

Cachorro, V.E, Burgos, M.A., Bennouna, Y., Toledano, C., Torres, B., Mateos, D., Marcos, A., de Frutos, A.M., 2014. Characterization of PMx data belonging to the desert-dust-inventory based on AOD-aplha RIMA-AERONET data at Palencia-Autilla stations. In Proceedings Book of 
the $2^{\text {st }}$ Iberian Meeting Aerosol Science and Technology RICTA 2014, Tarragona, Spain. Edited by Joan Rosell-Llompart, Jordi Grifoll. Available at http://digital.publicacionsurv.cat/index.php/purv/ catalog/book/65.

Cusack, M., Alastuey, A., Pérez, N., Pey, J., Querol, X., 2012. Trends of particulate matter (PM2.5) and chemical composition at a regional background site in the Western Mediterranean over the last nine years (2002-2010). Atmos. Chem. Phys. 12, 8341-8357. DOI:10.5194/acp-12-83412012.

Delucchi, M.A., Murphy, J.J., McCubbin, D.R., 2002. The health and visibility cost of air pollution: a comparison of estimation methods. J. Environ. Manage. 64, 139-152. DOI:10.1006/jema.2001.0515.

Dubovik, O., Holben, B., Eck, T.F., Smirnov, A., Kaufman, Y.J., King, M.D., Tanré, D., Slutsker, I., 2002. Variability of absorption and optical properties of key aerosol types observed in worldwide locations. J. Atmos. Sci. 59, 590-608.

EC. Directive 1999/30/EC of the European Parliament and of the Council (22 April 1999) relating to limit values for sulphur dioxide and oxides of nitrogen, PM and lead in ambient air. Official Journal of the European Communities 1999; L 163: 41-60.

EC. Directive 2008/50/EC of the European Parliament and of the Council (21 May 2008) on Ambient Air Quality and Cleaner Air for Europe. Official Journal of the European Communities 2008; L 151: 1-44.

Eck, T., Holben, B., Reid, J., Dubovik, O., Smirnov, A., O’Neill, N., Slutsker, I., Kinne, S., 1999. Wavelength dependence of the optical depth of biomass burning, urban, and desert dust aerosols. J. Geophys. Res. 104, 31333-31349.

EMEP. EMEP/CCC-Report 1/95, EMEP Manual for Sampling and Chemical Analysis, rev 2002. Norwegian Institute for Air Research 1996; available at: http://www.nilu.no/projects/ccc/manual/index.html (last access: 10 March 2014).

EMEP. EMEP/CCC-Report 4/11, EMEP Transboundary Particulate Matter in Europe Status report 2011. Norwegian Institute for Air Research 2011; available at: http://www.nilu.no/projects/ccc/reports/emep4-2011.pdf (last access: 10 March 2014).

EMEP. EMEP/CCC-Report 3/2014, Data Report 2012 Acidifying and eutrophying compounds and particulate matter. Norwegian Institute for Air Research 2014; available at: http://www.nilu.no/projects/ccc/reports/cccr3-2014.pdf (last access: 1 October 2015).

Escudero, M., Castillo, S., Querol, X., Avila, A., Alarcón, M., Viana, M., Alastuey, A., Cuevas, E., Rodríguez, S., 2005. Wet and dry African dust episodes over eastern Spain. J. Geophys. Res. 110, D18208. DOI:10.1029/2004JD004731.

Escudero, M., Querol, X., Ávila, A., Cuevas, E., 2007. Origin of the exceedances of the European daily PM limit value in regional background areas of Spain. Atmos. Environ. 41, 730 744.

Estellés, V., Martínez-Lozano, J.A., Pey, J., Sicard, M., Querol, X., Esteve, A.R., Utrillas, M.P., Sorribas, M., Gangoiti, G., Alastuey, A., Rocadenbosch, F., 2012. Study of the correlation between columnar aerosol burden, suspended matter at ground and chemical components in a background European environment. J. Geophys. Res. 117, D04201. DOI:10.1029/2011JD016356.

Füssel, H.M., Jol, A., 2012. Climate Change, Impacts and Vulnerability in Europe 2012 an Indicator-based Report. Publications Office of the European Union 2012; Luxembourg.

Hess, M., Koepke, P., Schult, I., 1998 Optical properties of aerosols and clouds: the software package OPAC. B. Am. Meteorol. Soc. 79, 831-844.

Holben, B.N., Eck, T.F., Slutsker, I., Tanré, D., Buis, J.P., Setzer, A., Vermote, E., Reagan, J.A., Kaufman, Y.J., Nakajima, T., Lavenu, F., Jankowiak, I., Smirnov, A., 1998. AERONET - a federated instrument network and data archive for aerosol characterization. Remote Sens. Environ. $66,1-16$. 
Holben, B., Tanré, D., Smirnov, A., Eck, T., Slutsker, I., Abuhassan, N., Newcomb, W., Schafer, J., Chatenet, B., Lavenu, F., Kaufman, Y.J., Vande Castle, J., Setzer, A., Markham, B., Clark, D., Frouin, R., Halthore, R., Karneli, A., O’Neill, N.T., Pietras, C., Pinker, R.T., Voss, K., Zibordi, G., 2001. An emerging ground-based aerosol climatology: aerosol optical depth from AERONET. J. Geophys. Res. 106, 12067-12097.

Kacenelenbogen, M,, Léon, J.F., Chiapello, I., Tanré, D., 2006 Characterization of aerosol pollution events in France using ground-based and POLDER-2 satellite data. Atmos. Chem. Phys. $6,4843-4849$.

Kaskaoutis, D.G., Badarinath, K.V.S., Kharol, S.K., Sharma, A.R., Kambezidis, H.D., 2009. Variations in the Aerosol optical properties and Types over the tropical urban site of Hyderabad, India. J. Geophys., Res. 114, D22204, DOI: 10.1029/2009JD012423.

Kim, D.H., Sohn, B.J., Nakajima, T., Takamura, T., Choi, B.C., Yoon, S.C., 2004. Aerosol optical properties over east Asia determined from ground-based sky radiation measurements. J. Geophys. Res. 109, D02209. DOI:10.1029/2003JD003387.

Kokhanovsky, A.A., Prikhach, A.S., Katsev, I.L., Zege, E.P.n 2009. Determination of particulate matter vertical columns using satellite observations. Atmos. Meas. Tech. 2, 327-335. DOI:10.5194/amt-2-327-2009.

Kumar, K.R., Sivakumar, V., Reddy, R.R., Gopal, K.R., Adesina, A.J., 2014. Identification and classification of different aerosol types over a subtropical rural site in Mpumalanka, South Africa: Seasonal variations retrieved from the AERONET sunphotometer. Aerosol Air Qual. Res. $14,108-123$.

Mateos, D., Sanchez-Lorenzo, A., Antón, M., Cachorro, V.E., Calbó, J., Costa, M.J., Torres, B., Wild, M., 2014. Quantifying the respective roles of aerosols and clouds in the strong brightening since the early 2000s over the Iberian Peninsula. J. Geophys. Res. (Atmos) 119, 10382-10393. DOI:10.1002/2014JD022076.

Mateos, D., Cachorro, V.E., Toledano, C., Burgos, M.A., Bennouna, Y., Torres, B., Fuertes, D., González, R., Guirado, C., Calle, A., de Frutos, A.M., 2015. Columnar and surface aerosol load over the Iberian Peninsula establishing annual cycles, trends, and relationships in five geographical sectors. Sci. Total Environ. 518-519, 378-392. DOI:10.1016/j.scitotenv.2015.03.002.

Pey, J., Querol, X., Alastuey, A., Forastiere, F., Stafoggia, M., 2013. African dust outbreaks over the Mediterranean Basin during 2001-2011: PM10 concentrations, phenomenology and trends, and its relation with synoptic and mesoscale meteorology. Atmos. Chem. Phys. 13, 1395-1410, DOI:10.5194/acp-13-1395-2013.

Pope III, C.A., 2000. Review: epidemiological basis for particulate air pollution health standards. Aerosol Sci. Tech. 32, 4-14.

Pope III, C.A., Dockeri, D.W., 2006. Health effects of fine particulate air pollution: lines that connect. J. Air \& Waste Manage. Assoc. 56, 709-742.

Pelletier, B., Santer, R., Vidot, J., 2007. Retrieving of particulate matter from optical measurements: A semiparametric approach. J. Geophys. Res. 112, D06208. DOI: 10.1029/2005JD006737.

Querol X, Pey J, Pandolfi M, Alastuey A, Cusack M, Pérez N, Moreno T, Viana M, Mihalopoulos N, Kallos G, Kleanthous S. African dust contributions to mean ambient PM10 masslevels across the Mediterranean Basin. Atmos Environ 2009; 43 : 4266-4277.

Querol X, et al. 2001-2012 trends on air quality in Spain. Sci Tot Env 2014; 490: 957-969.

Rodríguez S, Querol X, Alastuey A, Kallos G, Kakaliagou O. Saharan dust contributions to PM10 and TSP levels in southern and eastern Spain. Atmos Environ 2001; 35: 2433-2447.

Rohen, G.J., von Hoyningen-Huene, W., Kokhanovsky, A., Dinter, T., Vountas, M., Burrows, J.P., 2011. Retrieval of aerosol mass load (PM10) from MERIS/Envisat top of atmosphere spectral reflectance measurements over Germany. Atmos. Meas. Tech. 4, 523-534. 
Smirnov, A., Holben, B.N., Eck, T.F., Dubovik, O., Slutsker, I., 2000. Cloud-screening and quality control algorithms for the AERONET database. Remote Sens. Environ. 73, 337-349.

Toledano, C., Cachorro, V.E., Berjón, A., De Frutos, A., Sorribas, M., De la Morena B., Goloub, P., 2007a. Aerosol optical depth and Ångström exponent climatology at El Arenosillo AERONET site (Huelva, Spain). Q. J. Roy. Meteor. Soc. 133, 795-807.

Toledano, C., Cachorro, V.E., De Frutos, A., Sorribas, M., Prats, N., De la Morena, B., 2007b. Inventory of African desert dust events over the southwestern Iberian Peninsula in 2000-2005 with an AERONET Cimel Sun photometer. J. Geophys. Res. 112, D21201. DOI:10.1029/2006JD008307.

Toledano. C., Cachorro, V.E., de Frutos, A.M., Torres, B., Berjón, A., Sorribas, M., Stone, R.S., 2009. Airmass classification and analysis of aerosol types at El Arenosillo (Spain). J. Appl. Meteorol. Clim. 48, 962-981. DOI:10.1175/2008JAMC2006.1.

Toledano, C., Bennouna, Y., Cachorro, V., Ortiz de Galisteo, P., Stohl, A., Stebel, K., Kristiansen, N.I., Olmo. F.J., Lyamani, H., Obregón, M.A., Estelles, V., Wagner, F., Baldasano, J.M., González-Castanedo, Y., Clarisse, L., de Frutos, A., 2012. Aerosol properties of the Eyjafjallajökull ash derived from Sun photometer and satellite observations over the Iberian Peninsula. Atmos. Environ. 48, 22-32.

Tørseth, K., Aas, W., Breivik, K., Fjæraa, A.M., Fiebig, M., Hjellbrekke, A.G., Lund Myhre, C., Solberg, S., Yttri, K.E., 2012. Introduction to the European Monitoring and Evaluation Programme (EMEP) and observed atmospheric composition change during 1972-2009. Atmos. Chem. Phys. 12, 5447-5481. DOI:10.5194/acp-12-5447-2012.

Vergaz, R., Cachorro, V.E., De Frutos, A.M., Vilaplana, J.M., De La Morena, B.A., 2005. Columnar characteristics of aerosols by spectroradiometer measurements in the maritime area of the Cadiz Gulf (Spain). Int. J. Climatol. 25, 1781-1804.

WHO. Air Quality Guidelines: Global Update 2005: Particulate Matter, Ozone, Nitrogen Dioxide and Sulphur Dioxide. World Health Organization 2006. WHO Regional Office for Europe. ISBN 9289021926. 
660

661

662

663

664

665

666

667

668

669

670

671

672

673

674

675

676

677

678

679

680

681

682

683

684

685

\section{Tables}

Table 1. Yearly statistics of EMEP PM $\mathrm{M}_{10}, \mathrm{PM}_{2.5}$, and AERONET AOD data counts in the region of study for the period 2003-2014.

\begin{tabular}{|c|c|c|c|}
\hline Year & $\begin{array}{c}\text { N. days and (\%) } \\
\text { PM}_{\mathbf{1 0}}\end{array}$ & $\begin{array}{c}\text { N. days and (\%) } \\
\mathbf{P M}_{\mathbf{2 . 5}}\end{array}$ & $\begin{array}{c}\text { N. days and (\%) } \\
\text { AOD-AE }\end{array}$ \\
\hline 2003 & $330(90.41 \%)$ & $317(86.85 \%)$ & $156(42.74 \%)$ \\
\hline 2004 & $338(92.35 \%)$ & $329(89.89 \%)$ & $265(72.40 \%)$ \\
\hline 2005 & $330(90.41 \%)$ & $340(93.15 \%)$ & $295(80.82 \%)$ \\
\hline 2006 & $339(92.88 \%)$ & $324(88.77 \%)$ & $190(52.05 \%)$ \\
\hline 2007 & $336(92.05 \%)$ & $327(89.59 \%)$ & $271(74.25 \%)$ \\
\hline 2008 & $317(86.61 \%)$ & $320(87.43 \%)$ & $280(76.50 \%)$ \\
\hline 2009 & $329(90.14 \%)$ & $321(87.95 \%)$ & $256(70.14 \%)$ \\
\hline 2010 & $331(90.68 \%)$ & $326(89.32 \%)$ & $244(66.85 \%)$ \\
\hline 2011 & $340(93.15 \%)$ & $339(92.88 \%)$ & $269(73.70 \%)$ \\
\hline 2012 & $315(86.07 \%)$ & $334(91.26 \%)$ & $252(68.85 \%)$ \\
\hline 2013 & $328(89.86 \%)$ & $336(92.05 \%)$ & $220(60.27 \%)$ \\
\hline 2014 & $316(86.58 \%)$ & $310(84.93 \%)$ & $249(68.22 \%)$ \\
\hline Mean & $\mathbf{3 2 9}(90.12 \%)$ & $\mathbf{3 2 6}(89.53 \%)$ & $\mathbf{2 4 5 ( 6 7 . 2 5 \% )}$ \\
\hline Total & $\mathbf{3 9 4 9}$ & $\mathbf{3 9 2 3}$ & $\mathbf{2 9 4 7}$ \\
\hline
\end{tabular}

(1) 
686

687

688

689

690

691

692

693

694

695

696

697

698

699

700

701

702

703

704
Table 2. Monthly statistics of the AOD $(440 \mathrm{~nm})$ and AE parameters for the period 2003-2014 based on daily values, with the number of days (with percentage in parentheses), mean, median, percentiles (P25, P75, P5, P95), minimum (Min) and maximum (Max) values.

Aerosol Optical Depth, AOD

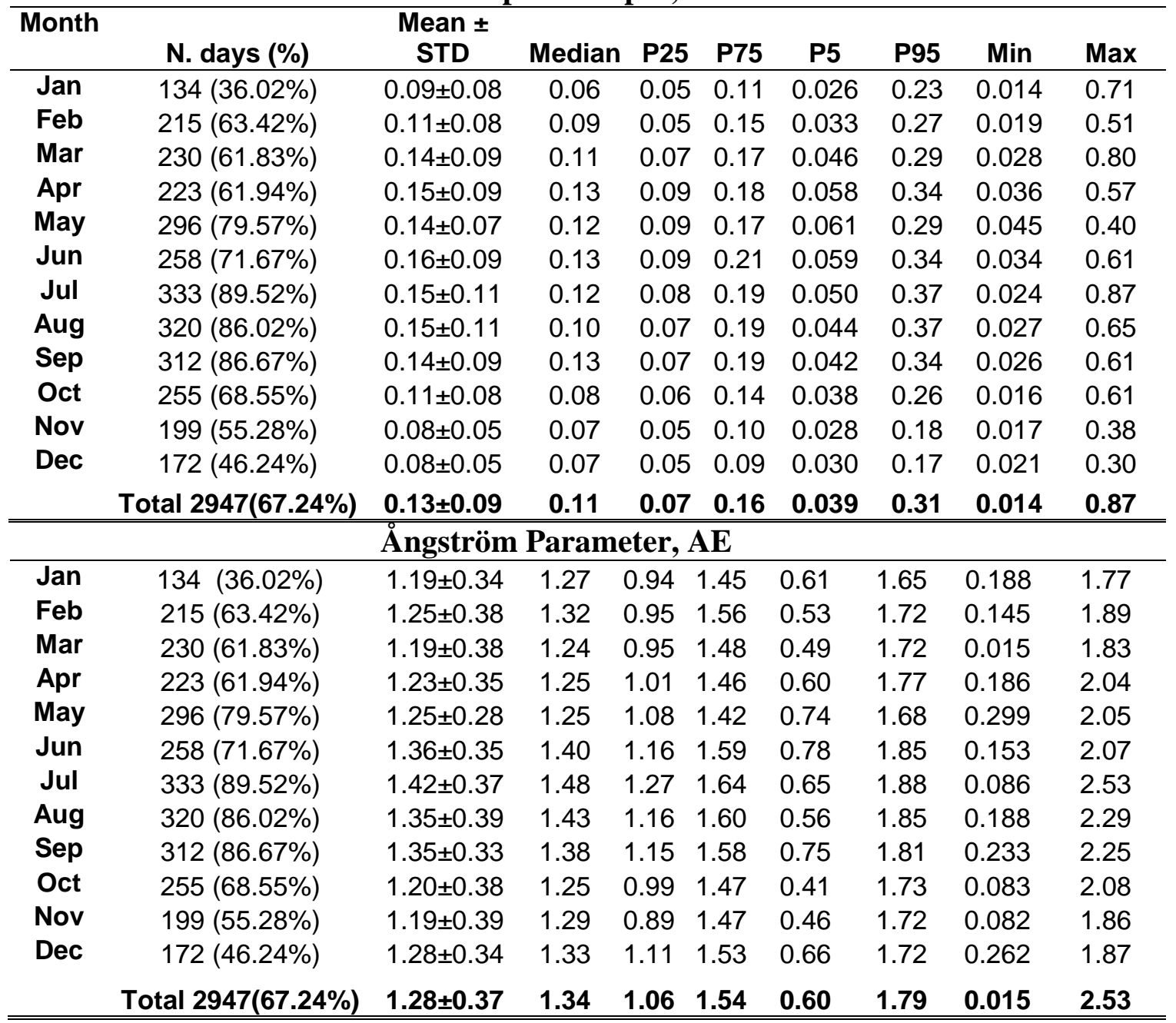


705

706

707

708

709

710

711

712

713

714

715

716

717

718

719

720

721

722

723

724

725

726

727

728
Table 3. Monthly statistics of the $\mathrm{PM}_{10}$ and $\mathrm{PM}$ ratio for the period 2003-2014 based on daily values, with the number of days (with percentage in parentheses), mean, median, percentiles (P25, P75, P5, P95), minimum (Min) and maximum (Max) values.

$\mathbf{P M}_{10}$

\begin{tabular}{cccccccccc}
\hline Month & N. days (\%) & Mean \pm STD & Median & P25 & P75 & P5 & P95 & Min & Max \\
\hline Jan & $281(75.54 \%)$ & $6.9 \pm 4.9$ & 5 & 4 & 8 & 3 & 17 & 2 & 36 \\
Feb & $297(87.61 \%)$ & $8.9 \pm 6.8$ & 7 & 4 & 12 & 3 & 22 & 1 & 50 \\
Mar & $344(92.47 \%)$ & $11.4 \pm 12.5$ & 8 & 5 & 13 & 3 & 29 & 2 & 143 \\
Apr & $332(92.22 \%)$ & $8.4 \pm 6.1$ & 7 & 5 & 10 & 3 & 18 & 2 & 48 \\
May & $352(94.62 \%)$ & $11.3 \pm 7.5$ & 9 & 7 & 14 & 4 & 25 & 2 & 68 \\
Jun & $336(93.33 \%)$ & $12.9 \pm 8.8$ & 10 & 8 & 15 & 5 & 27 & 3 & 90 \\
Jul & $356(95.70 \%)$ & $14.2 \pm 13.6$ & 11 & 9 & 16 & 6 & 29 & 4 & 197 \\
Aug & $354(95.16 \%)$ & $14.7 \pm 11.7$ & 11 & 8 & 16 & 6 & 35 & 3 & 94 \\
Sep & $331(91.94 \%)$ & $12.1+5.9$ & 11 & 7 & 15 & 5 & 23 & 3 & 39 \\
Oct & $342(91.94 \%)$ & $10.2 \pm 7.1$ & 8 & 5 & 12 & 3 & 24 & 2 & 45 \\
Nov & $321(89.17 \%)$ & $7.3 \pm 5.5$ & 6 & 4 & 8 & 3 & 15 & 2 & 49 \\
Dec & $303(81.45 \%)$ & $6.6 \pm 4.7$ & 5 & 4 & 8 & 3 & 14 & 2 & 39 \\
Total & $3949(90.1 \%)$ & $\mathbf{1 0 . 6} \pm 9.0$ & $\mathbf{8}$ & $\mathbf{5}$ & $\mathbf{1 3}$ & $\mathbf{3}$ & $\mathbf{2 5}$ & $\mathbf{1}$ & $\mathbf{1 9 7}$ \\
\hline \hline
\end{tabular}

$\mathbf{P M}$ ratio $\mathbf{P R}=\mathbf{P M}_{2.5} / \mathbf{P M}_{10}$

\begin{tabular}{cccccccccc} 
Total & $\mathbf{3 9 4 9}(\mathbf{9 0 . 1 \% )}$ & $\mathbf{1 0 . 6} \pm \mathbf{9 . 0}$ & $\mathbf{8}$ & $\mathbf{5}$ & $\mathbf{1 3}$ & $\mathbf{3}$ & $\mathbf{2 5}$ & $\mathbf{1}$ & $\mathbf{1 9 7}$ \\
\hline \hline Jan & $254(68.28 \%)$ & $0.63 \pm 0.17$ & 0.66 & 0.50 & 0.75 & 0.33 & 0.87 & 0.08 & 0.94 \\
Feb & $282(83.19 \%)$ & $0.63 \pm 0.18$ & 0.67 & 0.50 & 0.78 & 0.33 & 0.87 & 0.18 & 0.97 \\
Mar & $330(88.71 \%)$ & $0.60 \pm 0.16$ & 0.60 & 0.50 & 0.71 & 0.33 & 0.83 & 0.25 & 0.93 \\
Apr & $305(84.72 \%)$ & $0.60 \pm 0.14$ & 0.60 & 0.50 & 0.71 & 0.33 & 0.82 & 0.17 & 0.92 \\
May & $338(90.86 \%)$ & $0.58 \pm 0.14$ & 0.60 & 0.50 & 0.67 & 0.33 & 0.80 & 0.22 & 0.96 \\
Jun & $321(89.17 \%)$ & $0.58 \pm 0.13$ & 0.58 & 0.50 & 0.67 & 0.37 & 0.80 & 0.12 & 0.92 \\
Jul & $345(92.74 \%)$ & $0.58 \pm 0.12$ & 0.59 & 0.50 & 0.67 & 0.30 & 0.76 & 0.27 & 0.92 \\
Aug & $346(93.01 \%)$ & $0.57 \pm 0.12$ & 0.57 & 0.50 & 0.67 & 0.37 & 0.70 & 0.19 & 0.94 \\
Sep & $318(88.33 \%)$ & $0.56 \pm 0.12$ & 0.56 & 0.50 & 0.64 & 0.37 & 0.76 & 0.17 & 0.90 \\
Oct & $322(86.56 \%)$ & $0.53 \pm 0.14$ & 0.51 & 0.42 & 0.63 & 0.30 & 0.70 & 0.02 & 0.86 \\
Nov & $304(84.44 \%)$ & $0.55 \pm 0.15$ & 0.50 & 0.44 & 0.67 & 0.30 & 0.80 & 0.04 & 0.88 \\
Dec & $277(74.46 \%)$ & $0.61 \pm 0.16$ & 0.63 & 0.50 & 0.75 & 0.33 & 0.83 & 0.19 & 0.93 \\
Total & $\mathbf{3 7 4 2 ( 8 5 . 3 8 \% )}$ & $\mathbf{0 . 5 8} \pm \mathbf{0 . 1 5}$ & $\mathbf{0 . 6 0}$ & $\mathbf{0 . 5 0}$ & $\mathbf{0 . 6 8}$ & $\mathbf{0 . 3 3}$ & $\mathbf{0 . 8 2}$ & $\mathbf{0 . 0 4}$ & $\mathbf{0 . 9 7}$ \\
\hline \hline
\end{tabular}


Table 4. Yearly statistics of the AOD(440 nm) and AE parameters for the period 2003-2014 based on daily values, with the number of days (with percentage in parentheses), mean, median, percentiles (P25, P75, P5, P95), minimum (Min) and maximum (Max) values.

Aerosol Optical Depth, AOD

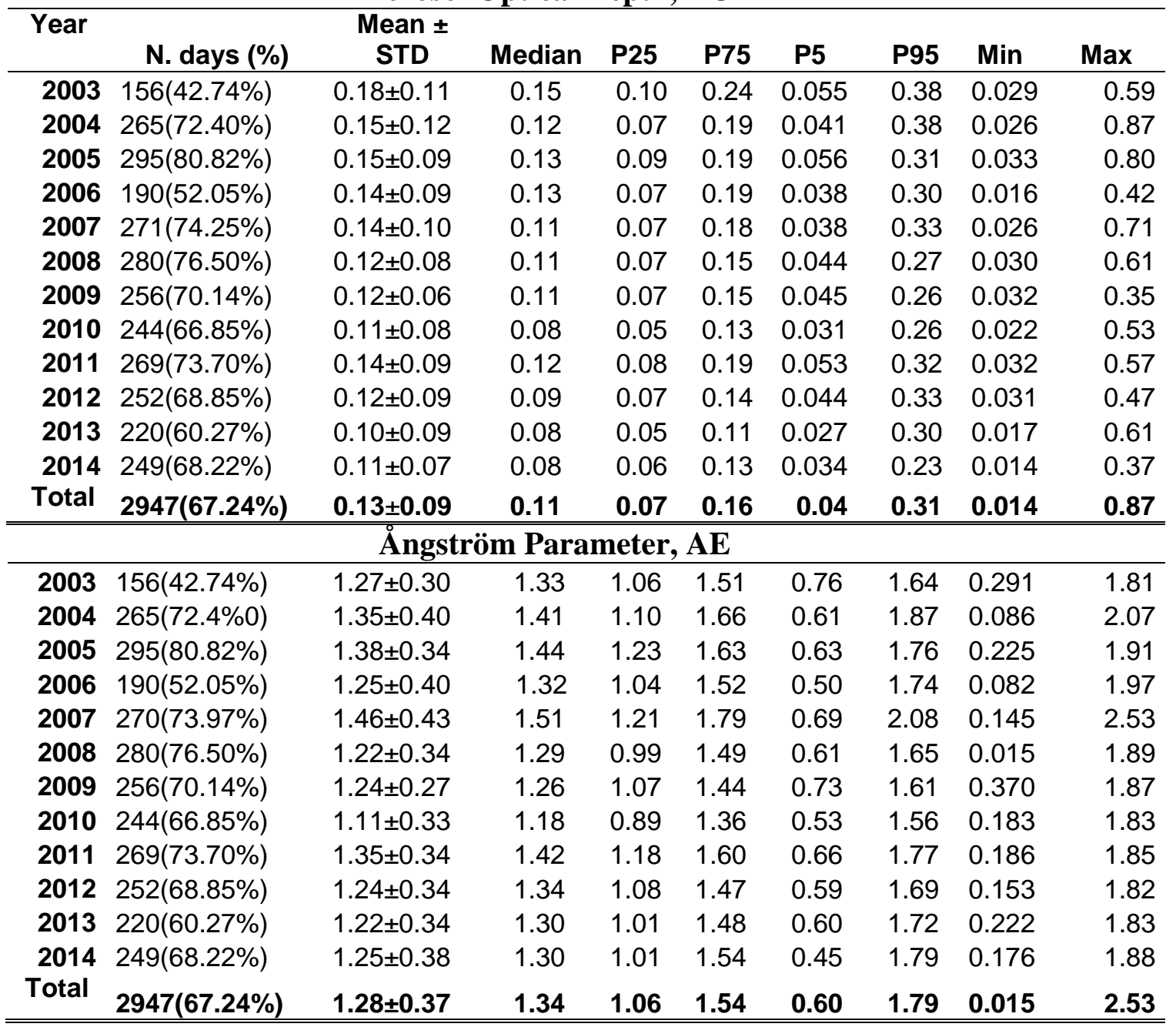

735

736

737

738

739

740

741

742

743

744

745

746

747

748

749

750

751

752 
753

754

755

756

757

758

759

760

761

762

763

764

765

766

767

768

769

770

771

772
Table 5. Yearly statistics of the $\mathrm{PM}_{10}$ and PM ratio for the period 2003-2014 based on daily values, with the number of days (with percentage in parentheses), mean, median, percentiles (P25, P75, P5, P95), minimum (Min) and maximum (Max) values.

$\mathbf{P M}_{10}$

\begin{tabular}{|c|c|c|c|c|c|c|c|c|c|}
\hline Year & N. days (\%) & Mean \pm STD & Median & P25 & P75 & P5 & P95 & Min & Max \\
\hline 2003 & $330(90.41 \%)$ & $13.02 \pm 10.0$ & 10 & 6 & 17 & 3 & 32 & 2 & 62 \\
\hline 2004 & $338(92.35 \%)$ & $13.45 \pm 14.70$ & 10 & 7 & 15 & 4 & 30 & 3 & 197 \\
\hline 2005 & 330(90.41\%) & $13.09 \pm 12.97$ & 10 & 6 & 16 & 4 & 29 & 2 & 143 \\
\hline 2006 & 339(92.88\%) & $11.30 \pm 7.44$ & 10 & 6 & 15 & 3 & 27 & 2 & 49 \\
\hline 2007 & 336(92.05\%) & $10.89 \pm 7.72$ & 9 & 6 & 13 & 4 & 23 & 1 & 68 \\
\hline 2008 & $317(86.61 \%)$ & $10.02 \pm 6.88$ & 9 & 5 & 13 & 3 & 24 & 2 & 45 \\
\hline 2009 & $329(90.14 \%)$ & $9.22 \pm 5.26$ & 8 & 5 & 12 & 3 & 19 & 2 & 34 \\
\hline 2010 & $331(90.68 \%)$ & $8.99 \pm 8.35$ & 8 & 5 & 11 & 3 & 18 & 2 & 94 \\
\hline 2011 & $340(93$ & \pm 6.99 & 9 & 5 & 12 & 3 & 23 & 2 & 48 \\
\hline 2012 & $315(86.07 \%)$ & +8.43 & 7 & 5 & 11 & 3 & 20 & 2 & 90 \\
\hline 2013 & $328(89.86 \%)$ & $8.15 \pm 5.57$ & 7 & 4 & 10 & 3 & 19 & 2 & 43 \\
\hline 2014 & $316(86$ & $8.84 \pm 6.27$ & 7 & 5 & 11 & 3 & 20 & 2 & 45 \\
\hline Total & 3949 & $10.56 \pm 9.01$ & 8 & 5 & 13 & 3 & 25 & 1 & 197 \\
\hline \multicolumn{10}{|c|}{$\mathrm{PM}$ ratio $\mathrm{PR}=\mathrm{PM}_{2.5} / \mathrm{PM}_{10}$} \\
\hline 2003 & $308(84.38 \%)$ & $0.63+0.13$ & 0.65 & 0.56 & 0.71 & 0.39 & 0.82 & 0.25 & 0.94 \\
\hline 2004 & $323(88.25 \%)$ & $0.66+0.13$ & 0.67 & 0.57 & 0.75 & 0.43 & 0.86 & 0.25 & 0.96 \\
\hline 2005 & $326(89.32 \%)$ & $0.63+0.14$ & 0.62 & 0.50 & 0.71 & 0.36 & 0.83 & 0.14 & 0.93 \\
\hline 2006 & $318(87.12 \%)$ & $0.62+0.15$ & 0.63 & 0.50 & 0.75 & 0.36 & 0.60 & 0.17 & 0.93 \\
\hline 2007 & $317(86.85 \%)$ & $0.60+0.14$ & 0.60 & 0.50 & 0.70 & 0.38 & 0.82 & 0.20 & 0.93 \\
\hline 2008 & 299(81.69\%) & $0.65+0.14$ & 0.67 & 0.57 & 0.75 & 0.40 & 0.86 & 0.17 & 0.94 \\
\hline 2009 & $315(86.30 \%)$ & $0.57+0.13$ & 0.56 & 0.50 & 0.67 & 0.37 & 0.77 & 0.24 & 0.90 \\
\hline 2010 & $319(87.40 \%)$ & $0.560+.13$ & 0.55 & 0.50 & 0.67 & 0.33 & 0.77 & 0.20 & 0.88 \\
\hline 2011 & $326(89.32 \%)$ & $0.53+0.14$ & 0.50 & 0.42 & 0.63 & 0.33 & 0.80 & 0.20 & 0.92 \\
\hline 2012 & 299(81.69\%) & $0.50+0.15$ & 0.50 & 0.39 & 0.62 & 0.29 & 0.75 & 0.19 & 0.97 \\
\hline 2013 & $305(83.56 \%)$ & $0.53+0.13$ & 0.55 & 0.44 & 0.63 & 0.33 & 0.73 & 0.08 & 0.86 \\
\hline 2014 & $287(78.63 \%)$ & $0.53+0.14$ & 0.50 & 0.42 & 0.63 & 0.30 & 0.79 & 0.04 & 0.92 \\
\hline Total & $3742(85.38 \%)$ & $0.58+0.15$ & 0.60 & 0.50 & 0.68 & 0.33 & 0.82 & 0.04 & 0.97 \\
\hline
\end{tabular}




\section{Figure Captions}

Figure 1. Map of the area of study showing the location of the EMEP site of Peñausende and the AERONET site of Palencia within the region of "Castilla y Leon" in Spain.

Figure 2. Monthly mean annual cycle based on daily data of a) AOD (440 nm) and $\mathrm{PM}_{10}$, b) Ångström exponent and PM ratio for the period 2003-2014.

Figure 3. Evolution of yearly mean data for a) AOD (440 nm) and $\mathrm{PM}_{10}$, b) Angstrom exponent and PM ratio for the period 2003-2014.

Figure 4. Scatterplots of AE vs. AOD for $(a, b)$ daily and $(c, d)$ instantaneous data with the corresponding colour scale range of $(a, c) \mathrm{PM}_{10}$ and (b, d) PM ratio, for the period 2003-2014.

Figure 5. Scatterplots of $\mathrm{PM}$ ratio vs. $\mathrm{PM}_{10}$ daily data with the colour scale range for (a) AOD and (b) AE, for the period 2003-2014.

Figure 6. Scatterplots of $\mathrm{PM}_{10}$ vs. AOD daily data with the colour scale range for (a) $\mathrm{AE}$ and (b) PM ratio, for the period 2003-2014.

Figure 7. Scatterplots of $\mathrm{PM}_{10}$ vs. AOD taking (a) daily, (b) monthly and (c) yearly values with associated linear fits.

Figure 8. Scatterplots of PM ratio vs. AE daily data with the colour scale range for (a) AOD and (b) $\mathrm{PM}_{10}$, for the period 2003-2014.

Figure 9. $\mathrm{PM}_{10}$ as a function of (a) binned AOD data and (c) binned AE data. Idem for PM ratio respectively $(b, d)$. The bars represent the standard deviation for EMEP data within each bin. The data counts for each bin (relative occurrence) are also shown on the superimposed histogram. 


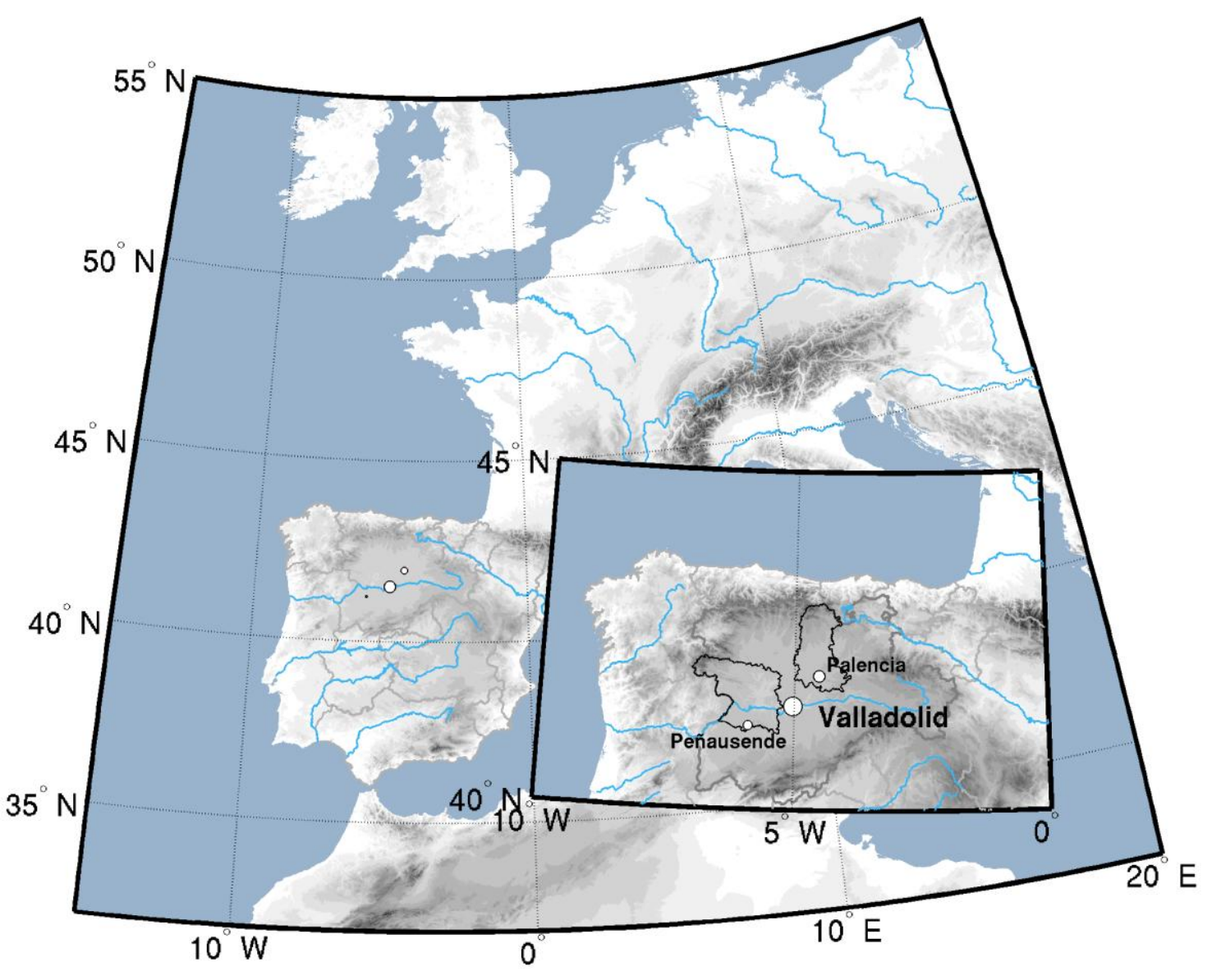

823

Figure 1

824

825

826

827

828

829

830

831

832

833

834

835

836

837

838

839

840

841 


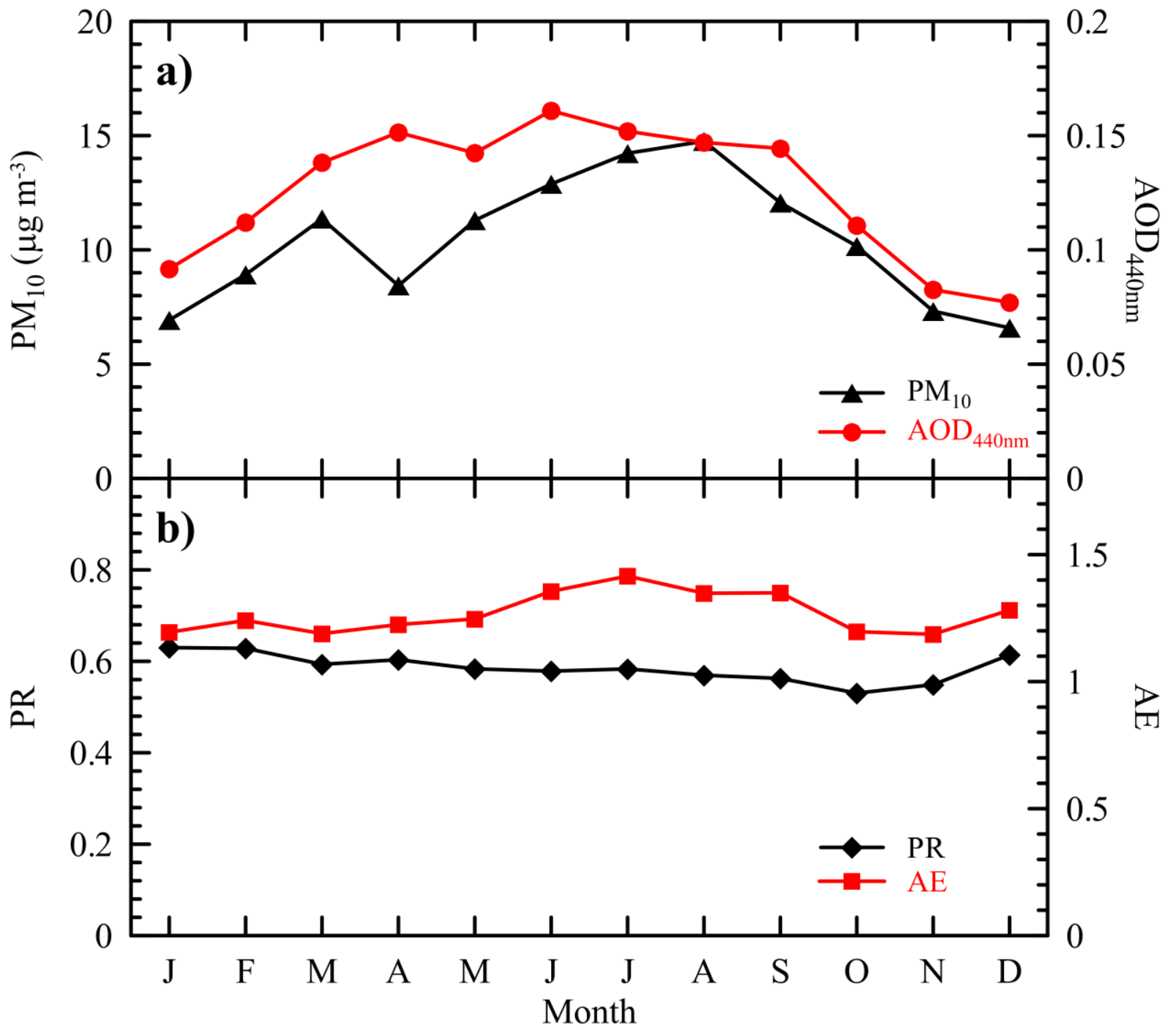

Figure 2 
860

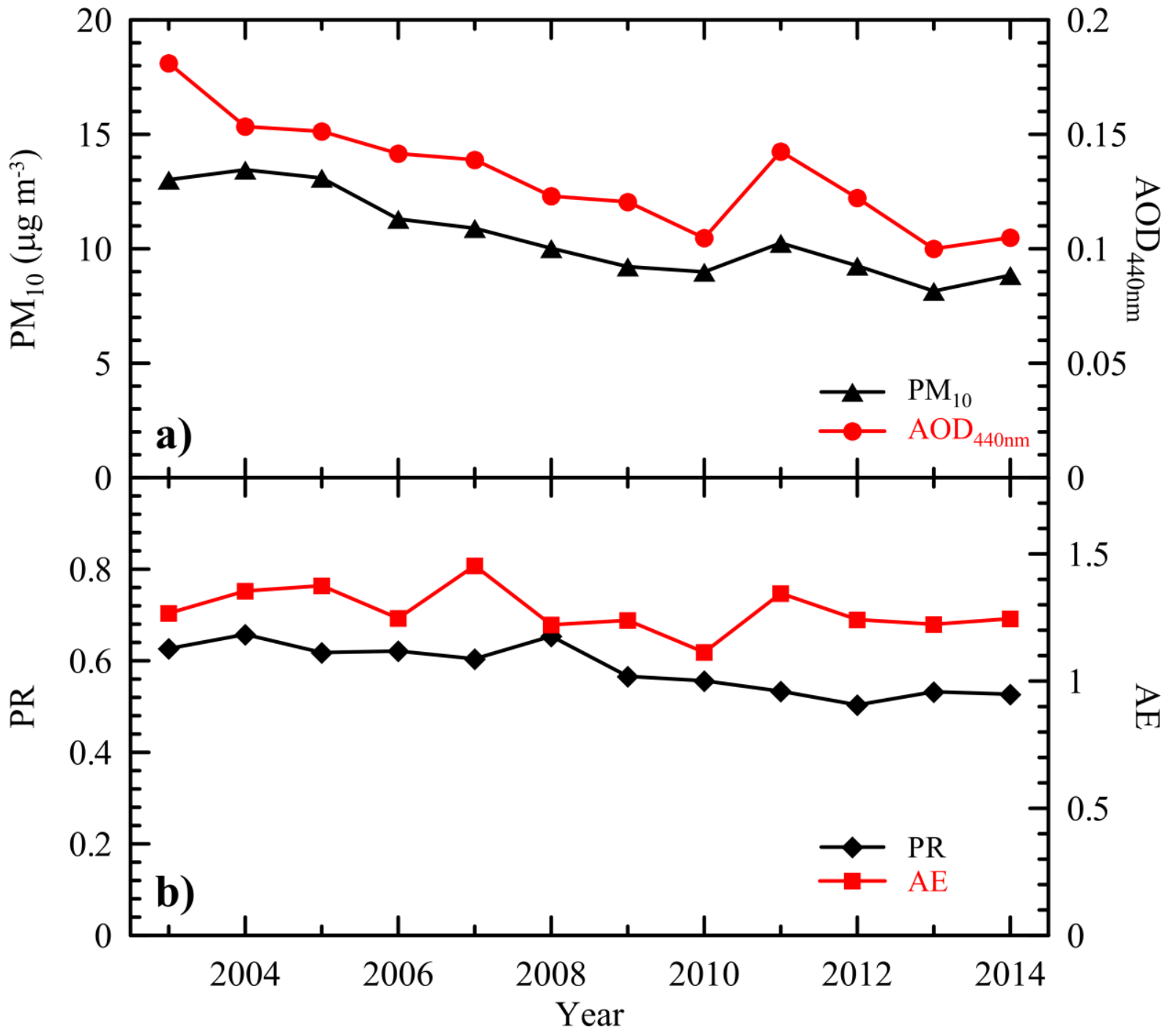

Figure 3

862

863

864

865

866

867

868

869

870

871

872

873 

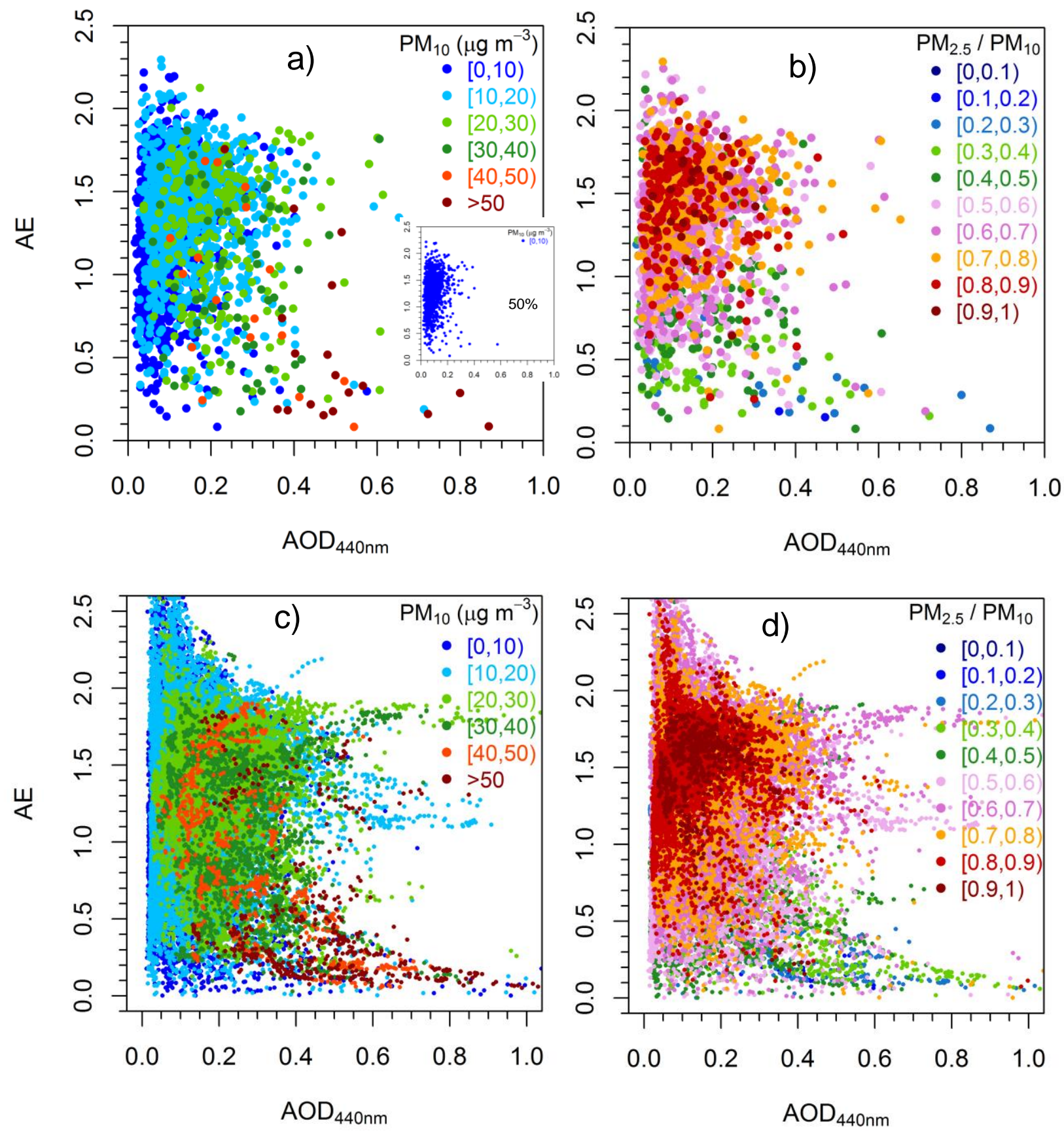

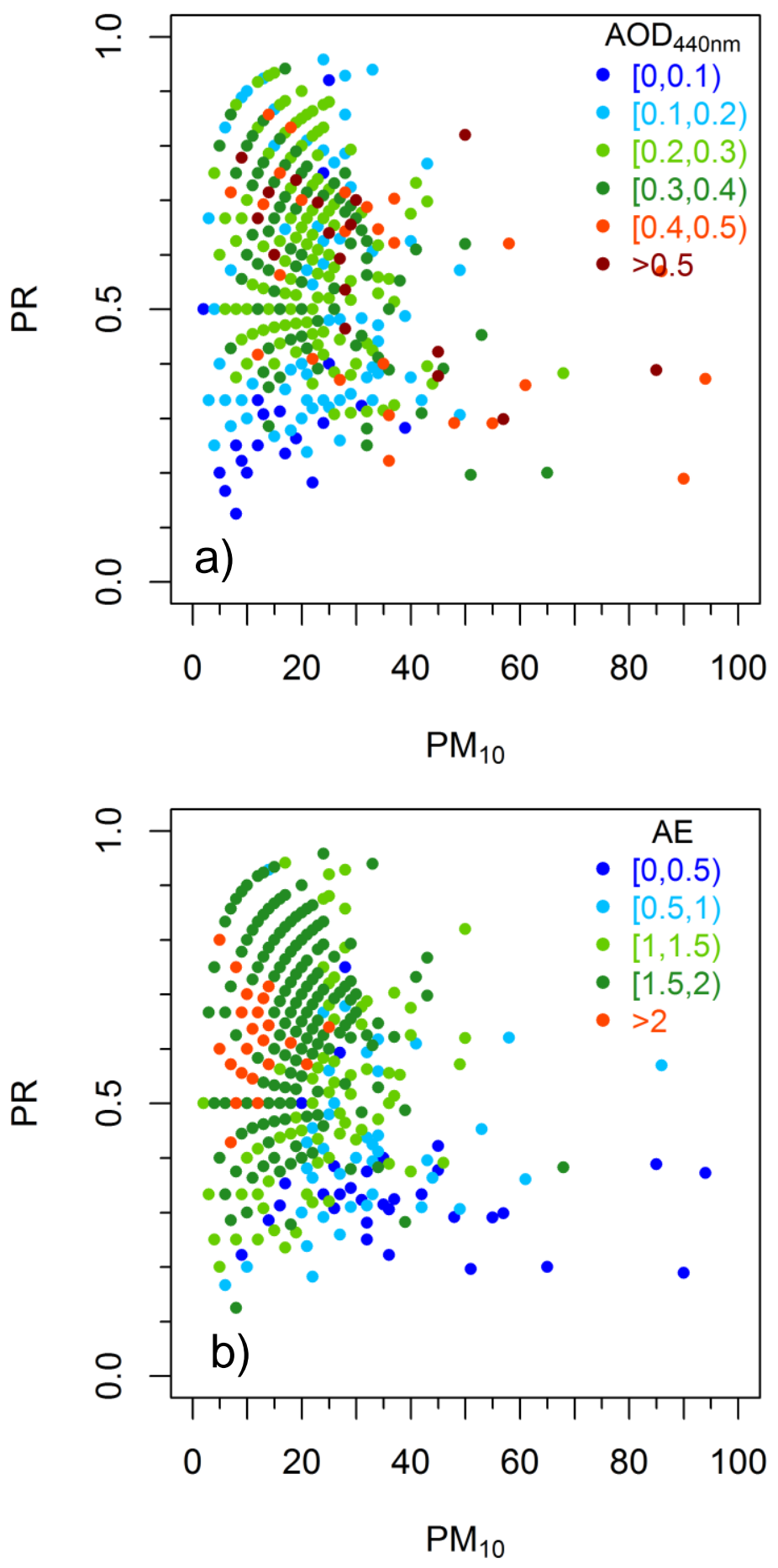

Figure 5

885

886

887 

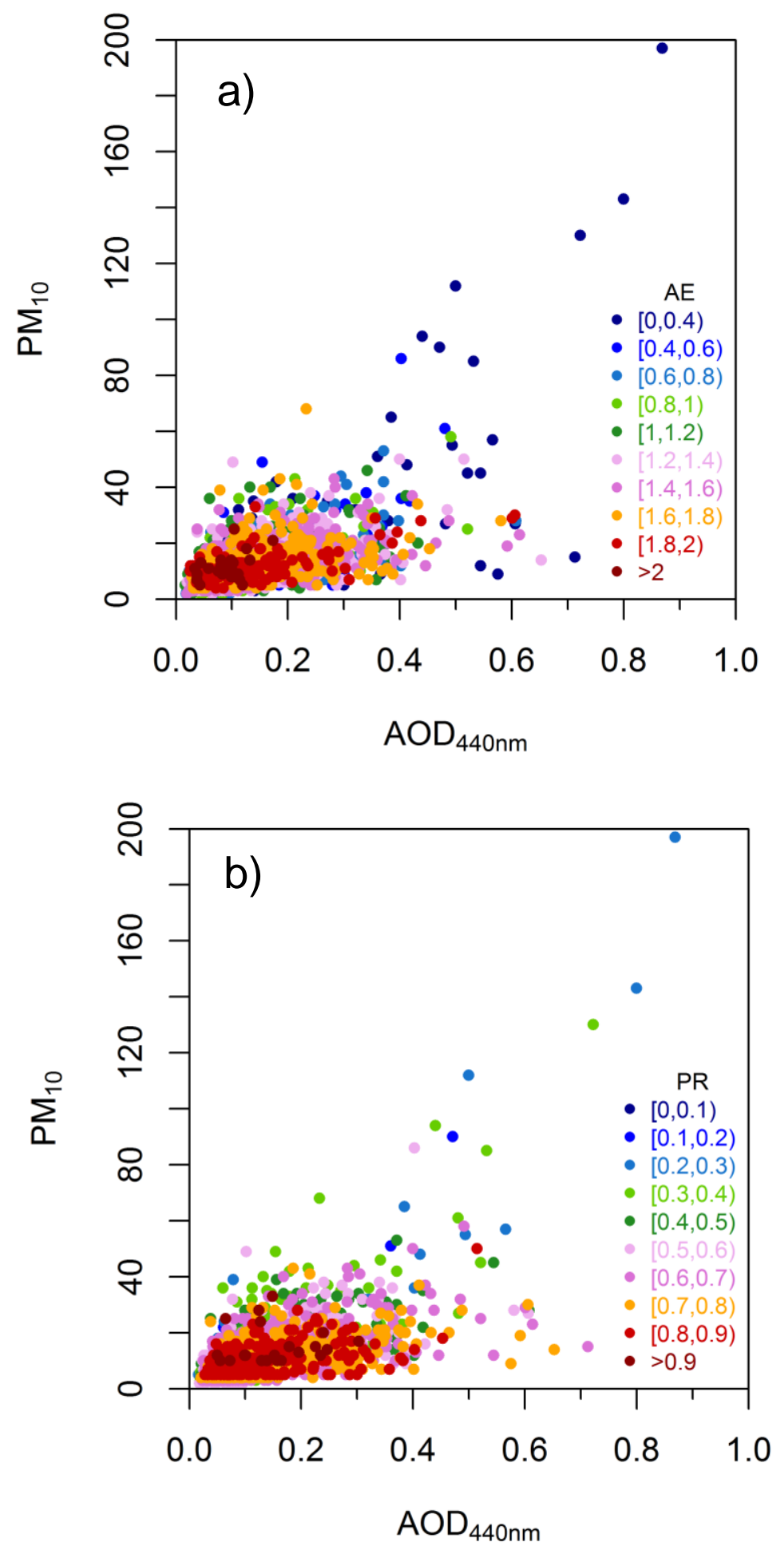

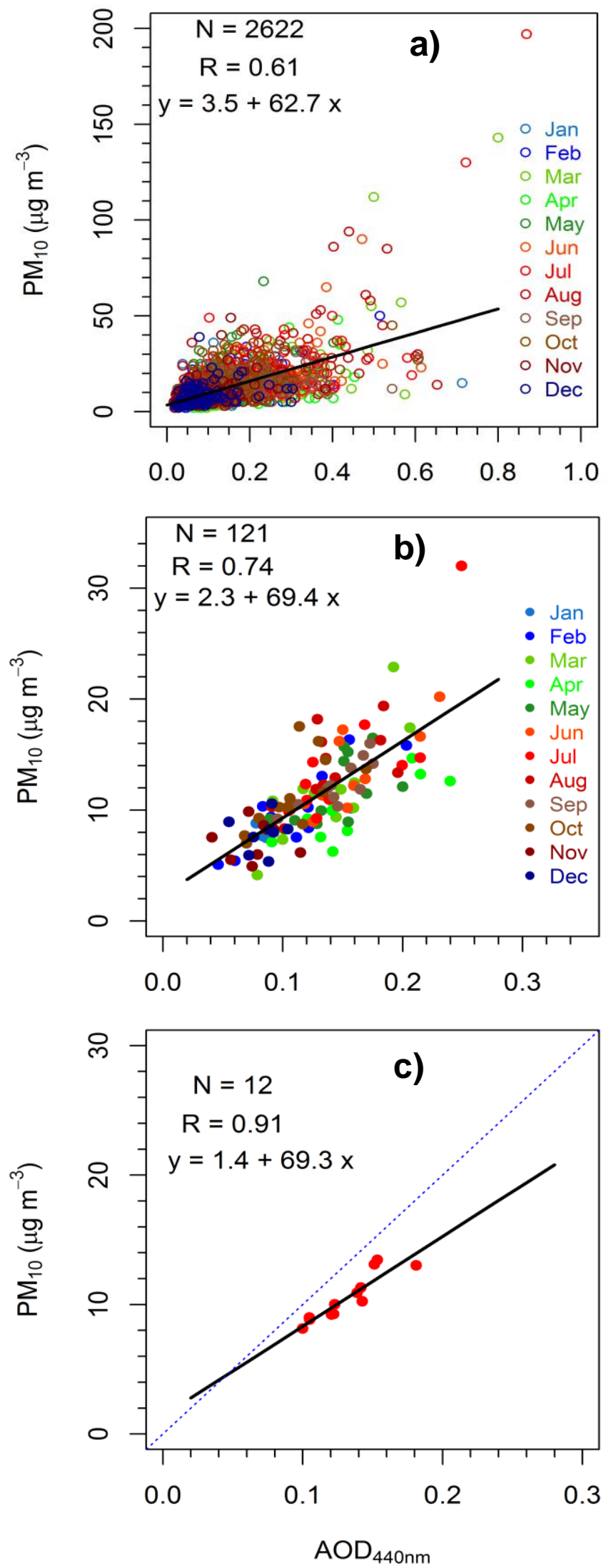
898

899

900

901

902

903

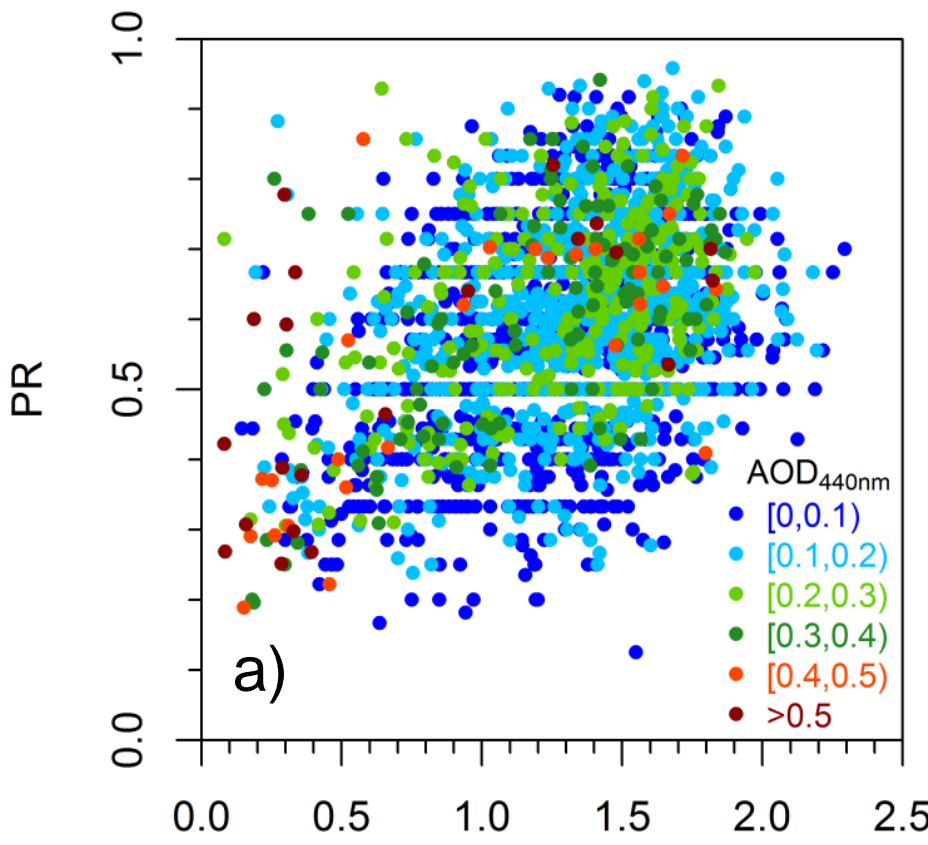

AE

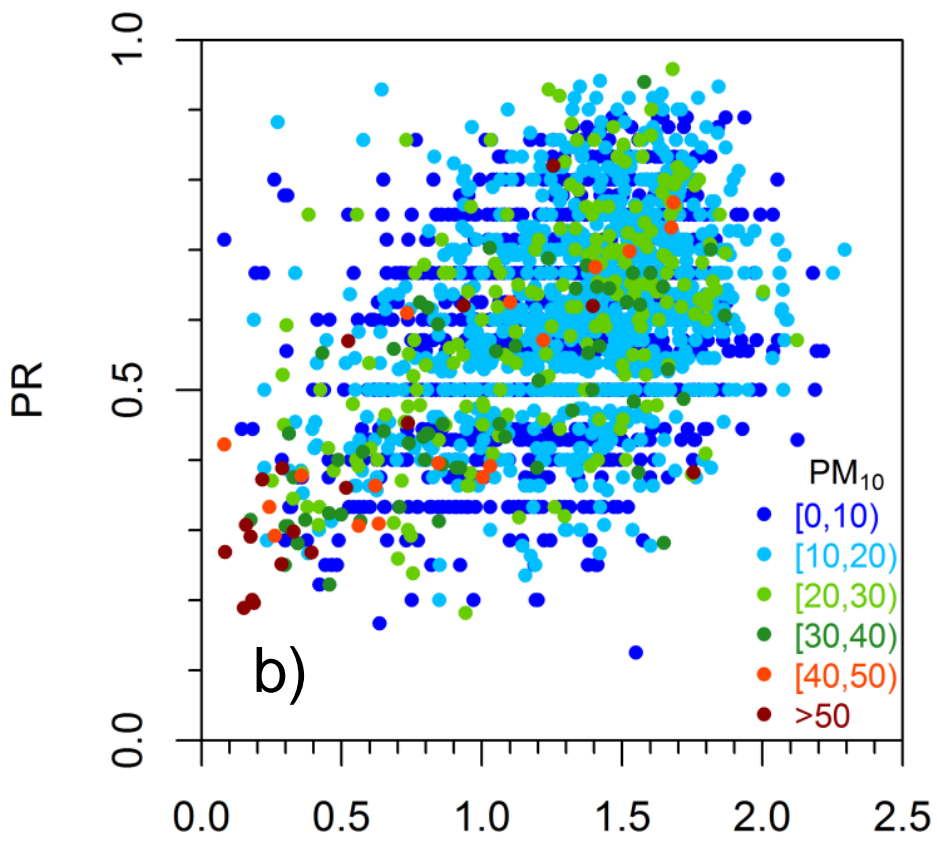

AE 
906

907

908

909
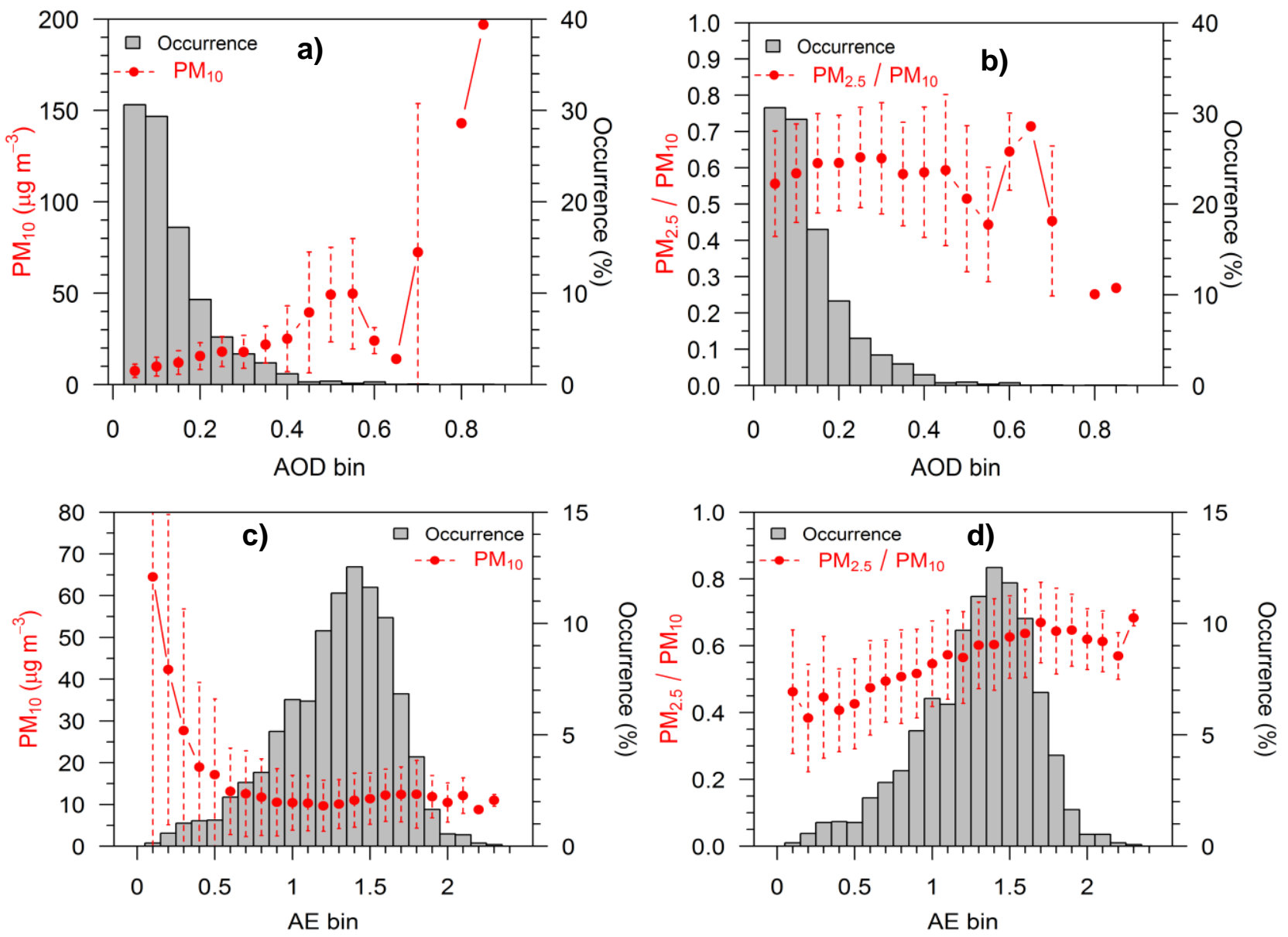

Figure 9 